\title{
Article
}

\section{Teladorsagia Circumcincta Galectin-Mucosal Interactome in Sheep}

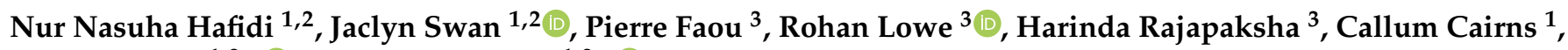 \\ Michael Stear $1,2, *(\mathbb{D})$ and Travis Beddoe $1,2, *$ (D)
}

1 Department of Animal, Plant and Soil Science and Centre for AgriBioscience (AgriBio), La Trobe University, Bundoora 3086, Australia; N.Hafidi@latrobe.edu.au (N.N.H.); j.swan@latrobe.edu.au (J.S.); c.cairns@latrobe.edu.au (C.C.)

2 Centre for Livestock Interactions with Pathogens (CLiP), La Trobe University, Melbourne 3086, Australia

3 Department of Biochemistry \& Genetics, La Trobe Institute for Molecular Science La Trobe University, Melbourne 3086, Australia; P.Faou@latrobe.edu.au (P.F.); R.Lowe@latrobe.edu.au (R.L.);

K.Rajapaksha@latrobe.edu.au (H.R.)

* Correspondence: m.stear@latrobe.edu.au (M.S.); t.beddoe@latrobe.edu.au (T.B.); Tel.: +61-3-9032-7448 (M.S.); $+61-3-9032-7400$ (T.B.)

Citation: Hafidi, N.N.; Swan, J.;

Faou, P.; Lowe, R.; Rajapaksha, H.;

Cairns, C.; Stear, M.; Beddoe, T.

Teladorsagia Circumcincta

Galectin-Mucosal Interactome in

Sheep. Vet. Sci. 2021, 8, 216.

https://doi.org/10.3390/

vetsci8100216

Academic Editor: Benjamin Dewals

Received: 30 July 2021

Accepted: 28 September 2021

Published: 4 October 2021

Publisher's Note: MDPI stays neutral with regard to jurisdictional claims in published maps and institutional affiliations.

Copyright: (C) 2021 by the authors. Licensee MDPI, Basel, Switzerland. This article is an open access article distributed under the terms and conditions of the Creative Commons Attribution (CC BY) license (https:// creativecommons.org/licenses/by/ $4.0 /)$.

\begin{abstract}
Teladorsagia circumcincta is the most important gastrointestinal parasite in the livestock industry in temperate regions around the world, causing great economic losses. The infective thirdstage larvae (L3) of Teladorsagia circumcincta secrete a large number of excretory-secretory (E/S) molecules, some of which are likely to play critical roles in modulating the host immune response. One of the most abundant E/S molecules is a protein termed Tci-gal-1, which has similarity to mammalian galectins. Galectins are a family of carbohydrate-binding molecules, with characteristic domain organisation and affinity for $\beta$-galactosids that mediate a variety of important cellular functions including inflammation and immune responses. To understand the role of Tci-gal-1 at the host-parasite interface, we used a proteomics pull-down approach to identify Tc-gal-1 interacting proteins from sheep abomasal scrapes and whole tissue. A total of 135 unique proteins were identified from whole abomasal tissue samples, while 89 proteins were isolated from abomasal scrape samples. Of these proteins, 63 were present in both samples. Many of the host proteins identified, such as trefoil factors and mucin-like proteins, play critical roles in the host response. The identification of Tci-gal-1 binding partners provides new insights on host-parasite interactions and could lead to the development of new control strategies.
\end{abstract}

Keywords: galectin; parasite-host interaction; proteomics; Teladorsagia circumcincta

\section{Introduction}

Gastrointestinal (GI) nematodes cause significant production and economic losses to livestock industries worldwide [1,2]. Infection with GI nematodes result in significant production losses estimated at approximately 500 million AUD in Australia and 38 million Euro in Europe every year [3,4], while anthelmintics alone are estimated to cost tens of billions of dollars annually worldwide [1,5]. The current control methods are becoming less effective due to the rapid emergence of anthelmintic resistance [6-8]. Sustainable control solutions such as vaccines or breeding for enhanced resistance are urgently needed. Increased knowledge of the host-parasite interface would facilitate both approaches.

Of particular importance to the sheep industry is the GI nematode Teladorsagia circumcincta, the most significant cause of ovine parasitic gastroenteritis in temperate regions around the world [9]. Infection with T. circumcincta elicits a T helper type 2 (Th2) immune response and stimulates the expression of defence mechanisms, including cytokines, immunoglobulins and eosinophils $[6,10]$. The establishment of infection may cause clinical signs such as weight loss, reduced appetite, profuse scouring, and occasionally, death [11]. 
The modulation of the host immune response by T. circumcincta allows the parasite to persist for long periods of time within the ruminant host [12,13]. This is achieved through the stage-specific release of excretory/secretory (E/S) proteins such as proteases, venom allergen-like proteins, lectins, and other enzymes by the parasite to maintain a state of active suppression $[12,14]$. These E/S proteins are fundamental for parasite survival in the host, playing a role in host tissue penetration and the feeding and evasion of the host's anti-parasitic immune response [15]. Each species of helminth secretes unique immunomodulatory molecules capable of targeting different aspects of the host immune response, establishing favourable conditions for parasite survival [16]. Disrupting the activity of these E/S proteins may lead to a quicker elimination of the parasite in a host [14]. An earlier in vitro proteomic study on T. circumcincta $\mathrm{E} / \mathrm{S}$ products revealed that infective L3 and L4 larval stages of T. circumcincta produce high levels of galectin [14].

Galectins are a family of $\beta$-galactoside-binding lectins that bind to glycans, such as lactose [17-20]. Galectins are characterised by the presence of at least one carbohydrate recognition domain (CRD) consisting of approximately 135 amino acid residues [21]. This family of proteins can be categorised into three groups: prototype galectins (single CRD), tandem repeat-type galectins (two CRDs with different glycan specificities) and chimeratype galectins (single CRD connected to a non-lectin amino-terminal region) [18,22,23] Previous studies have demonstrated the differing, and occasionally opposing, roles of galectin inside and outside the cell [24]. Galectins have been implicated in a variety of biological and immune processes such as host-pathogen recognition, cell adhesion, cell growth regulation, $\mathrm{T}$ cell polarisation and apoptosis [25].

Genes encoding tandem repeat-type galectins have been isolated from the ovine parasitic gastrointestinal nematodes T. circumcincta (Tci-gal-1 and Tci-gal-2), Haemonchus contortus (Hco-gal-1) and Trichostrongylus colubriformis (Tco-gal-2) [17], and have been hypothesised to be involved in parasite invasion and immunomodulation [22].

Tci-gal-1 is one of the most abundant E/S proteins secreted upon infection with a largely unknown function [14]. There is limited knowledge about this parasite galectin and the effects it could mediate within the infected host. This study is the first to explore Tci-gal1-binding molecules by using recombinant Tci-gal-1 to identify galectin glycoconjugates within the host abomasum in order to identify sheep glycoproteins in an endeavour to better understand host-parasite interactions.

\section{Materials and Methods}

\subsection{Sheep Tissue}

Three sheep abomasa collected from a local abattoir were cut along the greater curvature and thoroughly rinsed with MilliQ water to remove the contents. Whole cuts of tissue from the folds of each abomasum were taken, and mucosal scrapes were also prepared by gently scraping the surface of each abomasum using a microscope slide. The abomasal whole tissue (WT) and scrape (ST) samples were then washed with phosphate-buffered saline (PBS) (137 mM NaCl, $2.7 \mathrm{mM} \mathrm{KCl}, 1.8 \mathrm{mM} \mathrm{KH}_{2} \mathrm{PO}_{4}, 10 \mathrm{mM} \mathrm{Na} 2 \mathrm{HPO}_{4}, \mathrm{pH}$ 7.4), and $1 \mathrm{~g}$ aliquots of each sample were set up in triplicate in $2 \mathrm{~mL}$ microfuge tubes and frozen at $-80{ }^{\circ} \mathrm{C}$ for $20 \mathrm{~min}$. Two $3 \mathrm{~mm}$ glass beads (Qiagen, Hilden, Germany) were added to each tube and the samples were homogenised using the Qiagen TissueLyser II (Qiagen, Hilden, Germany) at $30 \mathrm{~Hz}$ for two rounds of $5 \mathrm{~min}$. The homogenised tissue was resuspended in an equal volume of $1 \%(w / v)$ sodium deoxycholate (DOC) dissolved in PBS and centrifuged at $16,000 \times g$ for $20 \mathrm{~min}$. The supernatant was collected and stored at $-80{ }^{\circ} \mathrm{C}$ until required.

\subsection{Tci-gal-1 Expression and Purification}

The Tci-gal-1 (NCBI accession number: U67147.1, https:/ / www.ncbi.nlm.nih.gov / (accessed on 20 March 2019)) gene was commercially synthesised and cloned into the pPICZ $\alpha$ vector (Invitrogen, Carlsbad, CA, USA) by Bioneer Pacific (Daejeon, South Korea) via the Pst I and Not I restriction enzyme sites. The subsequent pPICZ $\alpha$-Tci-gal-1 plasmid 
translated an N-terminal alpha-factor signal sequence and a C-terminal hexahistidine tag flanking the Pichia pastoris codon optimised Tci-gal-1 gene. The pPICZ $\alpha$-Tci-gal-1 plasmid was linearised with Sac I digest (New England BioLabs Inc., Ipswich, MA, USA) and chemically transformed into P. pastoris X33 using the Pichia EasyComp ${ }^{\mathrm{TM}}$ Transformation Kit according to the manufacturer's instructions (Invitrogen, Carlsbad, CA, USA). The transformants were plated onto YEPD agar plates $(1 \%(w / v)$ yeast extract, $2 \%(w / v)$ peptone, $2 \%(w / v)$ dextrose, $2 \%(w / v)$ agar) containing Zeocin ${ }^{\mathrm{TM}}(100 \mu \mathrm{g} / \mathrm{mL})$ and incubated at $28{ }^{\circ} \mathrm{C}$ for 4 days. Single colonies were grown in $10 \mathrm{~mL}$ of YEPD broth to make a glycerol stock.

A starter culture of Tci-gal-1 P. pastoris cells was grown from a glycerol stock inoculated into $50 \mathrm{~mL}$ conical tubes containing $10 \mathrm{~mL}$ of YEPD and incubated at $28^{\circ} \mathrm{C}$ for $48 \mathrm{~h}$ in a shaking incubator (180 rpm) (NB-205LF, N-BIOTEK, Bucheon, Korea). The starter culture was used at a 1:40 ratio to inoculate $400 \mathrm{~mL}$ of fresh buffered methanol-complex (BMMY) medium $(1 \%(w / v)$ yeast extract, $2 \%(w / v)$ peptone, $1 \%(w / v)$ yeast nitrogen base, $100 \mathrm{mM}$ potassium phosphate $\mathrm{pH} 6.0$ and $0.5 \%(v / v)$ methanol) in a $2 \mathrm{~L}$ baffled flask. The cultures were incubated for $96 \mathrm{~h}$ at $28^{\circ} \mathrm{C}$ whilst shaking $(160 \mathrm{rpm})$, with $0.5 \%(v / v)$ methanol added every $24 \mathrm{~h}$. Cells were pelleted at $6000 \times g$ for $30 \mathrm{~min}$ and the supernatant was dialysed using membrane tubing with a $12 \mathrm{kDa}$ molecular weight cut-off into starter buffer ( $5 \mathrm{mM}$ $\mathrm{NaH}_{2} \mathrm{PO}_{4} \mathrm{pH} 7.6,50 \mathrm{mM} \mathrm{NaCl}$ and $2 \mathrm{mM}$ imidazole) at $4{ }^{\circ} \mathrm{C}$ for $48 \mathrm{~h}$. Dialysis incubations were repeated at least three times with a minimum of $4 \mathrm{~h}$ between each exchange. The dialysed media were concentrated with the application of polyethylene glycol (PEG) 8000 (Astral Scientific, New South Wales, Australia) to the outside of the tubing and kept overnight at $4{ }^{\circ} \mathrm{C}$.

His-tagged Tci-gal-1 was purified from dialysed supernatant using nickel-nitrilotriacetic acid (Ni-NTA) affinity chromatography. Briefly, 2 mL of Ni-NTA agarose resin (His60 Ni Superflow Resin, Takara Bio Inc., Shiga, Japan) was added to a purification column and equilibrated with 10 bed volumes of starter buffer. Concentrated culture supernatants were added to the column and allowed to flow through by gravity at a rate of $1 \mathrm{~mL} / \mathrm{min}$. The resin was then washed with 2 column volumes of wash buffer (starter buffer containing $20 \mathrm{mM}$ imidazole). Bound proteins were eluted with $10 \mathrm{~mL}$ of elution buffer (starter buffer containing $250 \mathrm{mM}$ imidazole), followed by $5 \mathrm{~mL}$ of elution buffer containing $500 \mathrm{mM}$ imidazole. The elution fractions were pooled and buffer-exchanged using Amicon ${ }^{\circledR} 3 \mathrm{~K}$ Ultra-15 centrifugal filter units into storage buffer $\left(25 \mathrm{mM} \mathrm{NaH}_{2} \mathrm{PO}_{4}\right.$ and $250 \mathrm{mM} \mathrm{NaCl}, \mathrm{pH}$ 7.6) and stored at $4{ }^{\circ} \mathrm{C}$. Successful expression and purification of recombinant Tci-gal-1 was determined by $12 \%(w / v)$ SDS-PAGE and Coomassie brilliant blue R staining. Protein folding evaluation and identification was performed by circular dichroism spectroscopy [26] and mass spectrometry, respectively (Supplementary Figures S1 and S2).

\subsection{Determination of Lactose Binding Affinity}

The sugar binding affinity of Tci-gal-1 was determined using an assay similar to that described by Greenhalgh and Newton (1999). Briefly, $250 \mu \mathrm{g}$ of Tci-gal-1 was added to $25 \mu \mathrm{L}$ of lactose-Sepharose resin ( $\alpha$-Lactose-Agarose, Sigma-Aldrich, St. Louis, MO, USA) equilibrated with PBS containing $4 \mathrm{mM} \beta$-mercaptoethanol (MePBS). The suspension was incubated on a rotating wheel at room temperature for $1 \mathrm{~h}$ and washed twice with $500 \mu \mathrm{L}$ MePBS before eluting with $300 \mu \mathrm{L}$ PBS containing $500 \mathrm{mM}$ lactose. The elution was separated by $12 \%(w / v)$ SDS-PAGE and visualised using Coomassie brilliant blue R staining.

\subsection{Conjugation of Tci-gal-1 Onto N-Hydroxysuccinamide (NHS)-Activated Sepharose}

Active Tci-gal-1 was conjugated to NHS-activated Sepharose beads (GE Healthcare Life Science, Pittsburgh, PA, USA) as modified from Swan et al. (2019). Briefly, Tci-gal-1 (21 mg) was added to $8 \mathrm{~mL}$ of NHS-activated Sepharose beads and allowed to couple on a rotating wheel for $16 \mathrm{~h}$ at $4{ }^{\circ} \mathrm{C}$, followed by $2 \mathrm{~h}$ at room temperature. The remaining active sites on the resin was blocked for $2 \mathrm{~h}$ at room temperature with $100 \mathrm{mM}$ Tris- $\mathrm{HCl} \mathrm{pH}$ 
8.5, $500 \mathrm{mM} \mathrm{NaCl}$ and $10 \mathrm{mM}$ tris-2-carboxyethyl-phosphine (TCEP). Then, the resin was washed three times for $10 \mathrm{~min}$ at room temperature with 10 volumes of two alternating wash buffers. Wash buffer 1 contained $100 \mathrm{mM}$ Tris- $\mathrm{HCl} \mathrm{pH} \mathrm{8.8,500} \mathrm{mM} \mathrm{NaCl}$ and $10 \mathrm{mM}$ TCEP. Wash buffer 2 contained $100 \mathrm{mM}$ HEPES-HCl pH 6.8, $500 \mathrm{mM} \mathrm{NaCl}$ and $10 \mathrm{mM}$ TCEP. Galectin-conjugated Sepharose was stored in $100 \mathrm{mM}$ Tris- $\mathrm{HCl} \mathrm{pH}$ 8.0, $150 \mathrm{mM} \mathrm{NaCl}$ and $0.05 \%(w / v)$ sodium azide at $4{ }^{\circ} \mathrm{C}$.

\subsection{Sodium Periodate Treatment}

An aliquot of each lysate preparation was treated with $20 \mathrm{mM}$ sodium periodate dissolved in PBS and $50 \mathrm{mM}$ sodium acetate buffer ( $\mathrm{pH} 4.5$ ), as described by Schallig and van Leeuwen (1996). Glycan modification by periodate treatment was confirmed by conducting a lectin blot. Briefly, $20 \mu \mathrm{L}$ of $500 \mu \mathrm{g} / \mathrm{mL}$ of periodate treated and untreated whole tissue and scrape tissue were dotted onto a polyvinylidene difluoride (PVDF) membrane and probed with horseradish peroxidase conjugated Concanavalin A (ConAHRP) lectin (Sigma-Aldrich, St. Louis, MO, USA).

\subsection{Isolation of Tci-gal-1-Binding Ligands from Sheep Abomasal Tissue}

A batch-binding technique was used to capture Tci-gal-1-binding ligands from WT and ST lysates as well as sodium periodate treated WT and ST lysates $(n=3)$. The pull-down experiment was repeated three times from independent prepared lysates from different abomasal tissue.

Approximately $500 \mu \mathrm{g}$ of each lysate was incubated with $400 \mu \mathrm{g}$ of galectin conjugated Sepharose beads at room temperature for $3 \mathrm{~h}$ on a rotating wheel. Unbound proteins in the supernatant were removed by centrifugation at $500 \mathrm{xg}$ for $1 \mathrm{~min}$, followed by three washes with $600 \mu \mathrm{L}$ RIPA dialysis buffer $(20 \mathrm{mM}$ Tris- $\mathrm{HCl} \mathrm{pH}$ 8.0, $150 \mathrm{mM} \mathrm{NaCl}$, $0.5 \mathrm{mM}$ ethylenediaminetetraacetic acid (EDTA), $0.05 \%(v / v)$ Nonidet $\mathrm{P}-40,0.01 \%(w / v)$ DOC and $1 \%(v / v)$ Triton $X-100)$ for 10 min each. Captured ligands were eluted with $600 \mu \mathrm{L}$ of elution buffer $(250 \mathrm{mM}$ lactose, $20 \mathrm{mM}$ Tris- $\mathrm{HCl} \mathrm{pH} 8.0$ and $100 \mathrm{mM} \mathrm{NaCl})$ for $30 \mathrm{~min}$ at room temperature. The washed and eluted proteins were analysed by $12 \%(w / v)$ SDS-PAGE and visualised by silver staining.

Briefly, protein bands on the gels were fixed with $40 \%(v / v)$ methanol and $13.5 \%(v / v)$ formalin for $10 \mathrm{~min}$ immediately after electrophoresis. The gels were then washed twice in MilliQ water for $5 \mathrm{~min}$ each and soaked in $0.02 \%(w / v)$ sodium thiosulfate for $1 \mathrm{~min}$. After rinsing again with water, the gels were soaked for $10 \mathrm{~min}$ in $0.01 \%(w / v)$ silver nitrate and then in developing solution $(3 \%(w / v)$ sodium carbonate, $0.05 \%(v / v)$ formalin and $1.6 \times 10^{-5} \%(v / v)$ sodium thiosulfate) until protein bands were adequately intensified. The reaction was stopped with $2.3 \mathrm{M}$ citric acid.

\subsection{Mass Spectrometry}

Once the successful isolation of Tci-gal-1 glycoconjugates was confirmed, the eluted ligands were assessed using mass spectrometry (La Trobe University-Comprehensive Proteomics Platform (LTU-CPP), La Trobe University, Melbourne, Victoria). Eluted proteins were precipitated after adjustment to $0.02 \%(w / v)$ deoxycholate and $25 \%(v / v)$ trichloroacetic acid. The precipitated protein was washed in cold acetone before reconstitution in urea (8 M urea, $25 \mathrm{mM}$ Tris- $\mathrm{HCl}, \mathrm{pH}$ 8.0). Disulphide bonds were reduced by the addition of TCEP to $2 \mathrm{mM}$ for $60 \mathrm{~min}$, followed by the addition of iodoacetamide to $38 \mathrm{mM}$ for $45 \mathrm{~min}$ in the dark to alkylate the reduced thiols. The sample was then diluted with $20 \mathrm{mM}$ Tris- $\mathrm{HCl}$ to reduce the urea concentration below $1 \mathrm{M}$ before the addition of sequencing grade trypsin (Promega, Madison, WI, USA) to achieve a 1:50 ratio compared to the original protein amount. Trypsin digestion was completed overnight at $37^{\circ} \mathrm{C}$. Tryptic peptides were desalted and concentrated using StageTips according to Rappsilber et al. (2007).

Peptides were reconstituted in $0.1 \%(v / v)$ trifluoroacetic acid (TFA) and $2 \%(v / v)$ acetonitrile $(\mathrm{ACN})$, and $500 \mathrm{ng}$ of peptides were loaded onto $\mathrm{C}_{18}$ PepMap $100 \mu \mathrm{m}$ ID $\times$ 
$2 \mathrm{~cm}$ trapping column (Thermo-Fisher Scientific, Waltham, MA, USA) at $5 \mu \mathrm{L} / \mathrm{min}$ for $6 \mathrm{~min}$ and washed for $6 \mathrm{~min}$ before switching the pre-column in line with the analytical column (Acquity BHE $\mathrm{C}_{18}, 1.7 \mu \mathrm{m}, 130 \AA$ and $75 \mu \mathrm{m}$ ID $\times 25 \mathrm{~cm}$, Waters). The separation of peptides was performed at $250 \mathrm{nl} / \mathrm{min}$ using a linear ACN gradient of buffer A $(0.1 \%$ $(v / v)$ formic acid, $2 \%(v / v) \mathrm{ACN})$ and buffer B $(0.1 \%(v / v)$ formic acid, $80 \%(v / v) \mathrm{ACN})$, starting at 5\% buffer B to 35\% over $90 \mathrm{~min}$, then $50 \%$ B in $15 \mathrm{~min}$ followed by $95 \%$ B in $5 \mathrm{~min}$. The column was then cleaned for $5 \mathrm{~min}$ at $95 \%$ B following a 5 min equilibration step. Data were collected on a Thermo Orbitrap Eclipse (Thermo-Fisher Scientific, Waltham, MA, USA) in Data Dependent Acquisition mode using $m / z$ 350-1500 as MS scan range and HCD MS/MS spectra were collected in the orbitrap using a cycle time of $3 \mathrm{~s}$ per MS scan at 30,000 resolution. Dynamic exclusion parameters were set as follows: exclude isotope on, duration $60 \mathrm{~s}$ and using the peptide monoisotopic peak determination mode. Other instrument parameters for the instrument were: MS scan at 120,000 resolution, injection time Auto, AGC target Standard, HCD collision energy 30\%, injection time Auto with AGT target at Standard. The isolation window of the quadrupole for the precursor was $1.6 \mathrm{~m} / \mathrm{z}$.

\subsection{Protein Identification and Quantification}

Raw files consisting of high-resolution MS/MS spectra were processed with PEAKS Studio 10 (build) software program (Bioinformatics Solutions Inc., Waterloo, ON, Canada) [27]. Data were searched against an Ovis aries database (UniProt, June 2020). Additionally, the spectra was independently searched against the common contaminants database (common Repository of Adventitious Proteins (cRAP)—https:/ / www.thegpm.org/crap/ (accessed on 10 February 2020)). Briefly, signature MS/MS spectra were searched using PEAKS DB algorithms using the carbamidomethylation of cysteine as a fixed modification, and methionine oxidation as well as protein $\mathrm{N}$-termini acetylation set as a variable modification with up to three modifications allowed per peptide. The maximum number of missed cleavages by trypsin digestion was set to two. Mass tolerances were set to $\pm 10 \mathrm{ppm}$ for parent ions and $\pm 0.5 \mathrm{Da}$ for fragment ions. The minimum peptide length was set to 7 , with a maximum mass of $4600 \mathrm{Da}$. The minimum and maximum peptide length for unspecific cleavage were set at 8 and 25 amino acids, respectively. Protein and peptide spectrum matches (PSM) were reported at a false discovery rate (FDR) of $0.01 \%$. A label free quantification (LFQ) of the proteins was achieved using Andromeda, a built-in search engine within MaxQuant [28]. The label free quantification was done with 'Match between runs' using a match window of $0.7 \mathrm{~min}$. Large LFQ ratios were stabilised to reduce the sensitivity for outliers, and data was normalised using the 'Quantile' method. Redundant proteins were identified and removed from the raw mass spectrometry dataset, including captured proteins that were present in the negative controls, the cRAP database, as well as proteins that appeared in only one replicate. The average LFQ intensity of each remaining predicted protein was calculated and used to compare protein abundances.

\subsection{Protein Annotation and Glycosylation Analysis}

Unique proteins were identified by searching the accession number of each protein for matches within the Universal Protein Resource Knowledgebase (UniProtKB) consortium database (https: / / www.uniprot.org/) (accessed on 15 March 2020). The FASTA format protein sequences of uncharacterised proteins were scanned for conserved motifs against the InterPro 76.0 protein signature databases (http:/ / www.ebi.ac.uk/interpro/) (accessed on 15 March 2020), using the InterProScan tool. Additionally, the translated Basic Local Alignment Search Tool (tBLASTn) was used to search for regions of similarity of uncharacterised proteins between sequences in the National Center for Biotechnology Information (NCBI, USA) database. The functional annotations and cellular locations of each protein were predicted by assessing the domains and gene ontology (GO) terms of homologous proteins within UniProt and InterPro. The number of transmembrane domains and signal peptides were noted. Potential N- and O-glycosylation sites were predicted using the NetNGlyc 1.0 Server (http:/ / www.cbs.dtu.dk/services/NetNGlyc/) (accessed on 20 April 
2020) and NetOGlyc 4.0 Server (http:/ /www.cbs.dtu.dk/services/NetOGlyc/) (accessed on 20 April 2020) respectively.

\section{Results}

\subsection{Expression and Purification of Tci-gal-1}

Recombinant Tci-gal-1 was expressed in P. pastoris and purified by immobilised metalion affinity chromatography. The purified protein was analysed by SDS-PAGE and a single protein band at the expected molecular mass of $32.5 \mathrm{kDa}$ was seen, showing that Tci-gal-1 was successfully expressed and purified as a soluble protein (Figure 1A). Mass spectrometry was performed on the purified recombinant protein to confirm its identity.

To confirm if the recombinant Tci-gal- 1 was functional, lactose affinity chromatography was conducted [29]. Tci-gal-1 was shown to bind to the lactose-Sepharose beads and was eluted with lactose, indicating that Tci-gal-1 was showing lectin-binding activity (Figure 1B). It was apparent that Tci-gal-1 was seen in the wash fraction which may be due to the galectin overloading the resin binding capacity. Circular dichroism spectroscopy revealed a predominantly beta-sheet secondary structure, conforming to known spectra (Supplementary Figure S2) [30].

A

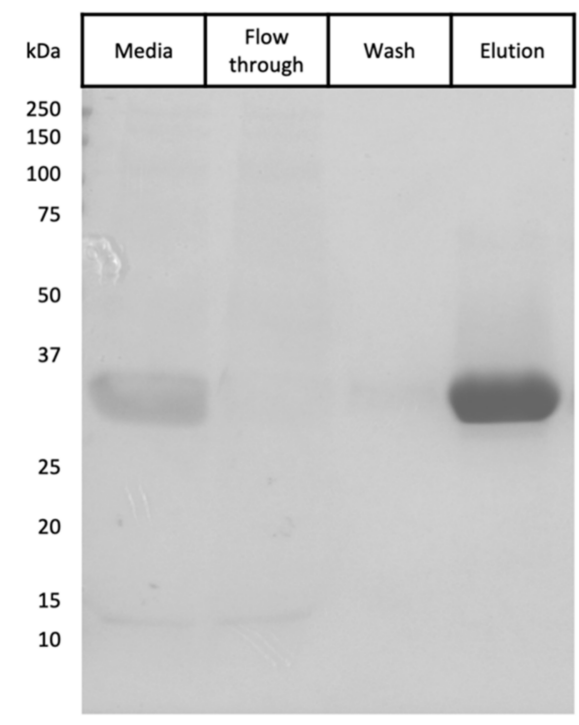

B

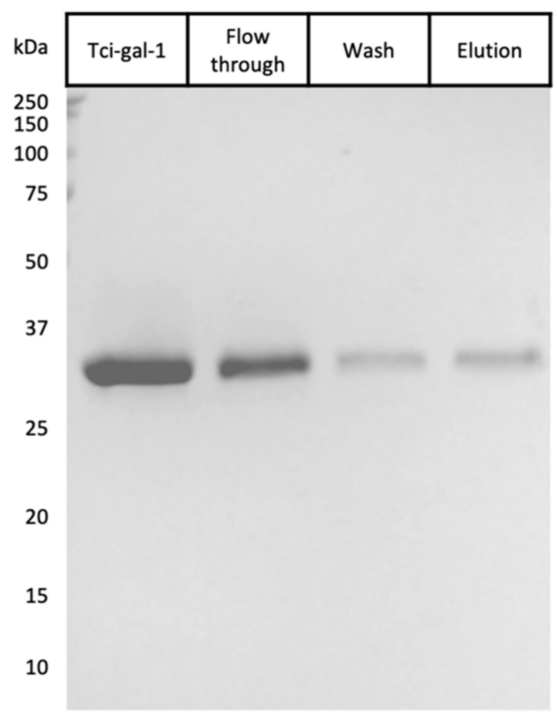

Figure 1. Purification and characterisation of Teladorsagia circumcincta galectin (Tci-gal-1). (A) Pichia pastoris media expressing Tci-gal-1 were applied to a NI-IDA column and washed once before elution with imidazole. A total of $15 \mu \mathrm{L}$ of each stage of the purification was resolved by SDS-PAGE and stained with Coomassie blue. (B) Purified recombinant Tci-gal-1 was shown to be functional by elution from a lactose-Sepharose column with lactose. Equal volumes $(15 \mu \mathrm{L})$ of each sample were analyzed by SDS-PAGE and visualised with Coomassie blue staining.

\subsection{Tci-gal-1-Binding Glycoproteins}

The elution profile of galectin-affinity chromatography from WT and ST lysates showed minimal differences between replicates. The treatment of lysates with $20 \mathrm{mM}$ sodium periodate successfully altered the glycan structures as demonstrated by the lectin dot blot (Figure 2), where the periodate-treated lysates were substantially less recognised by the lectin ConA. This suggests that the bands visualised on the silver stained SDS-PAGE showed non-specific binding of protein extracts to the resin complex in the negative controls (Figure 3). These non-specific proteins found in the periodate-treated controls were identified across the WT and ST dataset and were excluded (Supplementary Table S1). 


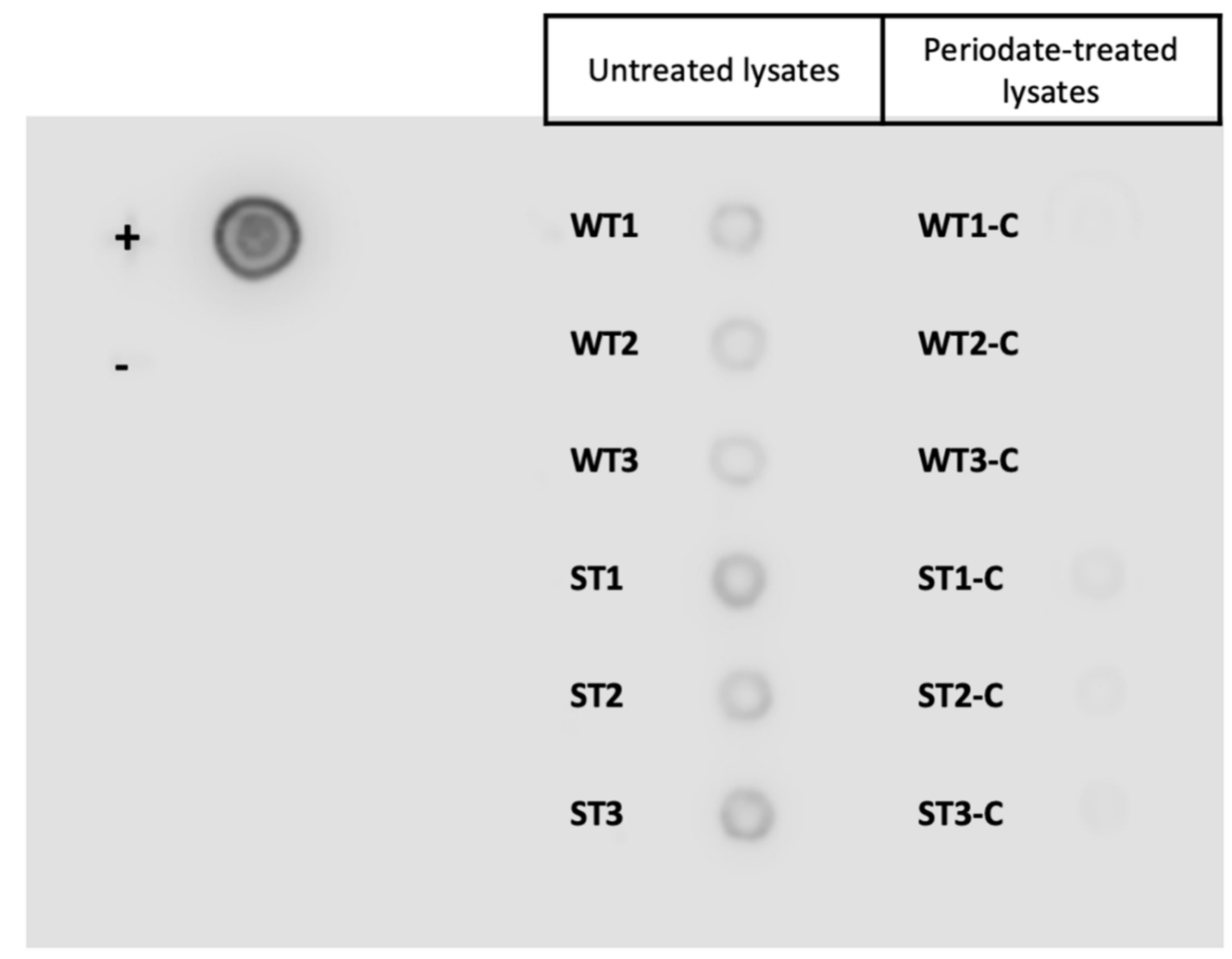

Figure 2. Confirmation of disruption of glycan structures by sodium periodate. ConA lectin dot blot confirming successful disruption of glycan structures after treatment of sheep abomasal whole tissue (WT) and scrape tissue (ST) with $20 \mathrm{mM}$ sodium periodate. Approximately $20 \mu \mathrm{L}$ of each sample was dotted onto a polyvinylidene difluoride (PVDF) membrane and probed with horseradish peroxidase conjugated Concanavalin A (ConA-HRP) lectin. (WT1-3) Biological replicates of abomasal whole tissue extracts. (ST1-3) Biological replicates of abomasal scrape extracts. ( $-\mathrm{C})$ Periodate-treated negative control samples. (+) Fasciola hepatica whole worm extract used as a positive control. (-) Periodate treated Fasciola hepatica whole worm extract used as negative control.

An analysis by MS/MS revealed a total of 990 and 821 proteins captured from the WT and ST lysates respectively, from a diversity of cellular locations and with varying functions. The WT pull-down assay identified 135 unique proteins (Figure $4 \mathrm{~A}$ ) which bound specifically to galectin conjugated Sepharose beads, while 855 proteins were identified as non-specific (Supplementary Table S2). The major cellular localisation of unique proteins was in the cell membrane and cytoplasm, with 31 proteins in each subcellular location. Transmembrane domains were identified in 27 of the 31 defined membrane proteins. The remaining proteins were found in the mitochondria (22/135), extracellular space $(12 / 135)$ nucleus $(11 / 135)$, endoplasmic reticulum (ER) $(9 / 135)$, cytoskeleton $(7 / 135)$, Golgi apparatus (5/135), ribosome (4/135) and the lysosome (3/135) (Figure 4A). Eleven of the 135 unique proteins demonstrated no predicted glycosylation sites (Supplementary Table S2). For example, the most abundant WT protein, Solute carrier family 25 member 31 , had no predicted glycosylation sites and was a mitochondrial protein. The top 50 most abundant WT proteins are displayed in Table 1. 


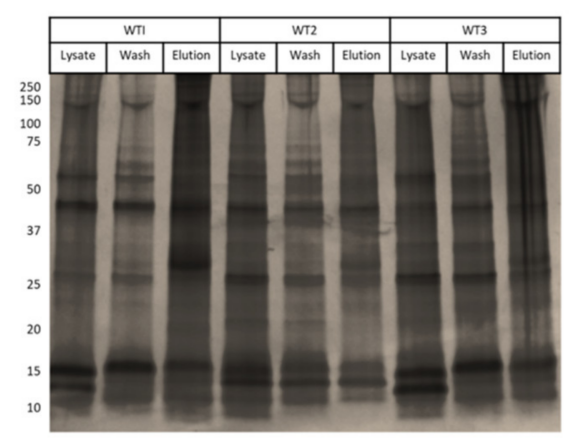

C

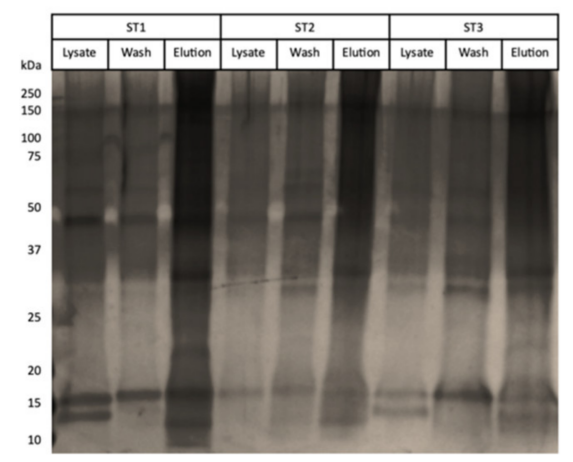

B

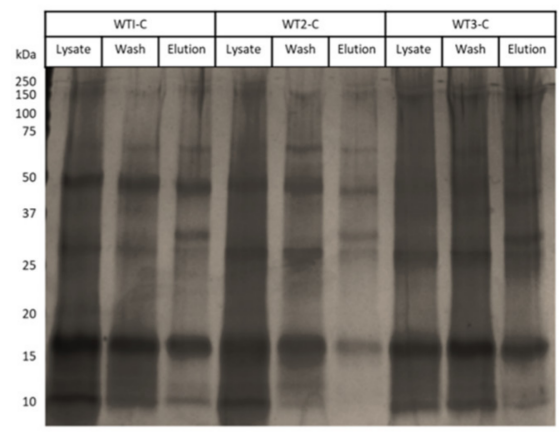

D

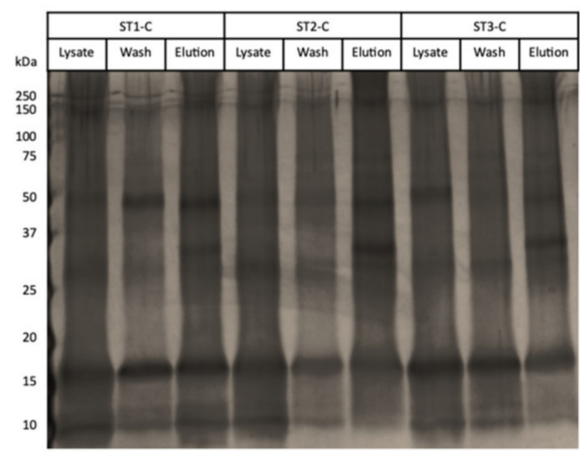

Figure 3. Protein profiles of abomasal whole tissue (WT) and abomasal scrape tissue (ST) extracts that bound to Tci-gal-1. Silver stained 12\% (w/v) SDS-PAGE gels showing protein abomasal whole tissue and scrape tissue lysates bound to immobilised Teladorsagia circumcincta galectin (Tci-gal-1). (A) Lysate, wash and elution prepared from sheep abomasal whole tissue added to immobilised Tci-gal-1, performed in triplicate. (B) Lysate, wash and elution prepared from sheep abomasal whole tissue, treated with $20 \mathrm{mM}$ sodium periodate, added to immobilised Tci-gal-1, performed in triplicate. (C) Lysate, wash and elution prepared from sheep abomasal scrape tissue added to immobilised Tci-gal-1, performed in triplicate. (D) Lysate, wash and elution prepared from sheep abomasal scrape tissue, treated with $20 \mathrm{mM}$ sodium periodate. 
Table 1. Identification by mass spectroscopy of top 50 most abundant sheep abomasal whole tissue (WT) proteins eluted from a Tci-gal-1 column.

\begin{tabular}{|c|c|c|c|c|c|c|c|c|c|c|c|}
\hline \multirow{2}{*}{$\begin{array}{l}\text { Accession } \\
\text { Number }\end{array}$} & \multirow[t]{2}{*}{ Gene ID } & \multirow[t]{2}{*}{ Protein Annotation } & \multirow{2}{*}{$\begin{array}{l}\text { Mol. Weight } \\
\text { (kDa) }\end{array}$} & \multirow{2}{*}{$\begin{array}{l}\text { Sequence } \\
\text { Length }\end{array}$} & \multirow{2}{*}{$\begin{array}{l}\text { Unique } \\
\text { Peptides }\end{array}$} & \multirow{2}{*}{$\begin{array}{c}\text { Average } \\
\text { Abundance } \\
\text { ( } \log _{2} \text { LFQ) }\end{array}$} & \multicolumn{2}{|c|}{$\begin{array}{c}\text { Number of Predicted } \\
\text { Glycosylation Sites }\end{array}$} & \multirow{2}{*}{$\begin{array}{l}\text { Signal } \\
\text { Peptides }\end{array}$} & \multirow{2}{*}{$\begin{array}{l}\text { Predicted } \\
\text { Cellular } \\
\text { Location }\end{array}$} & \multirow{2}{*}{$\begin{array}{l}\text { Predicted } \\
\text { Function }\end{array}$} \\
\hline & & & & & & & N-glycan & O-glycan & & & \\
\hline W5PCT5 & SLC25A31 & $\begin{array}{c}\text { Solute carrier family } 25 \\
\text { member } 31\end{array}$ & 28.72 & 262 & 6 & 24.86 & 0 & 0 & $\mathrm{~N}$ & Mitochondria & $\begin{array}{l}\text { Membrane } \\
\text { transport }\end{array}$ \\
\hline W5PLZ4 & TFF2 & Trefoil factor 2 & 14.31 & 131 & 2 & 24.57 & 0 & 1 & Y & Extracellular & $\begin{array}{l}\text { Regulatory } \\
\text { function }\end{array}$ \\
\hline W5P7F8 & CD63 & Tetraspanin & 25.83 & 236 & 4 & 24.37 & 4 & 0 & $\mathrm{~N}$ & $\begin{array}{l}\text { Cell } \\
\text { membrane }\end{array}$ & $\begin{array}{l}\text { Regulatory } \\
\text { function }\end{array}$ \\
\hline W5P0U4 & MUC1 & $\begin{array}{l}\text { SEA domain-containing } \\
\text { protein (Mucin } 1 \text { related) }\end{array}$ & 58.65 & 588 & 4 & 23.98 & 5 & 158 & $\mathrm{Y}$ & $\begin{array}{l}\text { Cell } \\
\text { membrane }\end{array}$ & $\begin{array}{l}\text { Regulatory } \\
\text { function }\end{array}$ \\
\hline W5PBS4 & LRP1 & $\begin{array}{l}\text { LDL receptor related } \\
\text { protein } 1\end{array}$ & 502.55 & 4526 & 14 & 23.56 & 33 & 122 & $\mathrm{~N}$ & $\begin{array}{l}\text { Cell } \\
\text { membrane }\end{array}$ & $\begin{array}{l}\text { Regulatory } \\
\text { function }\end{array}$ \\
\hline W5QAH5 & - & $\begin{array}{l}\text { Transcription factor, } \\
\text { GTP-binding domain }\end{array}$ & 30.79 & 277 & 1 & 23.51 & 2 & 1 & $\mathrm{~N}$ & Nucleus & Other \\
\hline W5QA42 & MFAP4 & $\begin{array}{l}\text { Fibrinogen C-terminal } \\
\text { domain-containing } \\
\text { protein }\end{array}$ & 21.42 & 193 & 2 & 23.38 & 1 & 0 & $\mathrm{Y}$ & Extracellular & $\begin{array}{l}\text { Metabolic } \\
\text { function }\end{array}$ \\
\hline W5PQ79 & RPS15 & Ribosomal protein S15 & 16.43 & 141 & 2 & 23.34 & 0 & 0 & $\mathrm{~N}$ & Ribosome & Other \\
\hline W5PZK7 & ACTA2 & $\begin{array}{c}\text { Actin alpha 2, smooth } \\
\text { muscle }\end{array}$ & 42.01 & 377 & 1 & 23.26 & 1 & 1 & $\mathrm{~N}$ & Cytoskeleton & $\begin{array}{l}\text { Regulatory } \\
\text { function }\end{array}$ \\
\hline W5PEN0 & ITGA1 & Integrin subunit alpha 1 & 129.29 & 1166 & 9 & 23.09 & 19 & 15 & Y & $\begin{array}{l}\text { Cell } \\
\text { membrane }\end{array}$ & $\begin{array}{l}\text { Regulatory } \\
\text { function }\end{array}$ \\
\hline P00922 & CA2 & Carbonic anhydrase 2 & 29.21 & 260 & 2 & 23.06 & 0 & 1 & $\mathrm{~N}$ & $\begin{array}{l}\text { Cell } \\
\text { membrane }\end{array}$ & Other \\
\hline W5PTZ9 & LOC114116824 & Histone $\mathrm{H} 3$ & 15.39 & 136 & 1 & 22.93 & 0 & 7 & $\mathrm{~N}$ & Nucleus & $\begin{array}{l}\text { Binding } \\
\text { function }\end{array}$ \\
\hline W5P8R7 & FCGBP & IgGFc-binding protein & 271.26 & 2544 & 17 & 22.92 & 10 & 44 & $\mathrm{Y}$ & Extracellular & $\begin{array}{l}\text { Binding } \\
\text { function }\end{array}$ \\
\hline W5PNH6 & FAM234A & $\begin{array}{c}\text { Family with sequence } \\
\text { similarity } 234 \text { member } \\
\text { A-related }\end{array}$ & 57.62 & 540 & 7 & 22.86 & 3 & 6 & $\mathrm{~N}$ & $\begin{array}{l}\text { Cell } \\
\text { membrane }\end{array}$ & Unknown \\
\hline W5QBH1 & CSRP1 & $\begin{array}{l}\text { Cysteine and glycine rich } \\
\text { protein } 1\end{array}$ & 18.72 & 175 & 2 & 22.59 & 3 & 7 & $\mathrm{~N}$ & Nucleus & $\begin{array}{l}\text { Binding } \\
\text { function }\end{array}$ \\
\hline W5QB48 & LOC101113624 & ATP synthase, subunit F & 10.84 & 93 & 2 & 22.59 & 0 & 3 & $\mathrm{~N}$ & Mitochondria & $\begin{array}{l}\text { Metabolic } \\
\text { function }\end{array}$ \\
\hline W5NWN0 & GSTZ1 & $\begin{array}{c}\text { Glutathione S-transferase } \\
\text { zeta } 1\end{array}$ & 26.7 & 240 & 4 & 22.54 & 4 & 1 & $\mathrm{~N}$ & Mitochondria & $\begin{array}{l}\text { Metabolic } \\
\text { function }\end{array}$ \\
\hline
\end{tabular}


Table 1. Cont.

\begin{tabular}{|c|c|c|c|c|c|c|c|c|c|c|c|}
\hline \multirow{2}{*}{$\begin{array}{l}\text { Accession } \\
\text { Number }\end{array}$} & \multirow[t]{2}{*}{ Gene ID } & \multirow[t]{2}{*}{ Protein Annotation } & \multirow{2}{*}{$\begin{array}{l}\text { Mol. Weight } \\
\text { (kDa) }\end{array}$} & \multirow{2}{*}{$\begin{array}{l}\text { Sequence } \\
\text { Length }\end{array}$} & \multirow{2}{*}{$\begin{array}{l}\text { Unique } \\
\text { Peptides }\end{array}$} & \multirow{2}{*}{$\begin{array}{c}\text { Average } \\
\text { Abundance } \\
\text { (Log } \text { LogQ) }_{2} \text { LF }\end{array}$} & \multicolumn{2}{|c|}{$\begin{array}{l}\text { Number of Predicted } \\
\text { Glycosylation Sites }\end{array}$} & \multirow{2}{*}{$\begin{array}{l}\text { Signal } \\
\text { Peptides }\end{array}$} & \multirow{2}{*}{$\begin{array}{l}\text { Predicted } \\
\text { Cellular } \\
\text { Location }\end{array}$} & \multirow{2}{*}{$\begin{array}{l}\text { Predicted } \\
\text { Function }\end{array}$} \\
\hline & & & & & & & N-glycan & O-glycan & & & \\
\hline W5PI50 & GLRX & $\begin{array}{c}\text { Glutaredoxin } \\
\text { domain-containing } \\
\text { protein }\end{array}$ & 11.81 & 106 & 2 & 22.53 & 1 & 0 & $\mathrm{~N}$ & Cytoplasm & $\begin{array}{l}\text { Regulatory } \\
\text { function }\end{array}$ \\
\hline W5NY03 & CD163 & $\begin{array}{l}\text { CD163, scavenger } \\
\text { receptor cysteine rich } \\
\text { domain }\end{array}$ & 122.35 & 1136 & 6 & 22.45 & 7 & 13 & $\mathrm{Y}$ & $\begin{array}{l}\text { Cell } \\
\text { membrane }\end{array}$ & Cell signalling \\
\hline W5Q5W2 & SCARB2 & $\begin{array}{l}\text { CD36, scavenger receptor } \\
\text { class B member } 2\end{array}$ & 49.78 & 439 & 5 & 22.38 & 9 & 0 & $\mathrm{~N}$ & Lysosome & $\begin{array}{l}\text { Binding } \\
\text { function }\end{array}$ \\
\hline W5QCQ4 & DHX9 & DExH-box helicase 9 & 142.13 & 1289 & 9 & 22.36 & 7 & 29 & $\mathrm{~N}$ & Nucleus & $\begin{array}{l}\text { Regulatory } \\
\text { function }\end{array}$ \\
\hline W5Q436 & SLC25A5 & $\begin{array}{l}\text { Mitochondrial carrier } \\
\text { protein }\end{array}$ & 29.33 & 263 & 3 & 22.34 & 1 & 0 & $\mathrm{~N}$ & Mitochondria & $\begin{array}{l}\text { Regulatory } \\
\text { function }\end{array}$ \\
\hline W5PPJ0 & STT3A & $\begin{array}{c}\text { STT3 oligosaccharyltrans- } \\
\text { ferase complex catalytic } \\
\text { subunit A }\end{array}$ & 90.02 & 789 & 5 & 22.34 & 1 & 1 & $\mathrm{~N}$ & ER & $\begin{array}{l}\text { Metabolic } \\
\text { function }\end{array}$ \\
\hline W5QD93 & LOC101119050 & $\begin{array}{l}\text { Dehydrogenase/reductase } \\
\text { SDR member 4-like }\end{array}$ & 29.6 & 279 & 3 & 22.31 & 1 & 3 & $\mathrm{~N}$ & Mitochondria & $\begin{array}{l}\text { Metabolic } \\
\text { function }\end{array}$ \\
\hline W5NTX6 & RIPK1 & $\begin{array}{c}\text { Receptor interacting } \\
\text { serine/threonine kinase } \\
1\end{array}$ & 87.21 & 770 & 1 & 22.26 & 2 & 38 & $\mathrm{~N}$ & Cytoplasm & $\begin{array}{l}\text { Regulatory } \\
\text { function }\end{array}$ \\
\hline W5PQK3 & PFKL & $\begin{array}{c}\text { ATP-dependent } \\
\text { 6-phosphofructokinase }\end{array}$ & 82.65 & 752 & 5 & 22.23 & 2 & 1 & $\mathrm{~N}$ & Cytoplasm & $\begin{array}{l}\text { Metabolic } \\
\text { function }\end{array}$ \\
\hline W5Q8K4 & SLC3A2 & $\begin{array}{l}\text { Solute carrier family } 3 \\
\text { member } 2\end{array}$ & 63.34 & 577 & 5 & 22.22 & 3 & 7 & $\mathrm{~N}$ & Cytoplasm & $\begin{array}{l}\text { Metabolic } \\
\text { function }\end{array}$ \\
\hline W5QFP1 & PABPC4 & $\begin{array}{l}\text { Polyadenylate-binding } \\
\text { protein }\end{array}$ & 72.31 & 660 & 2 & 22.19 & 0 & 8 & $\mathrm{~N}$ & Cytoplasm & $\begin{array}{l}\text { Binding } \\
\text { function }\end{array}$ \\
\hline W5PQS4 & PROCR & $\begin{array}{l}\text { MHC class 1-like antigen } \\
\text { recognition domain }\end{array}$ & 27.09 & 241 & 3 & 22.18 & 4 & 1 & Y & Cytoskeleton & Cell signalling \\
\hline W5QJ31 & MTHFD1 & $\begin{array}{l}\text { Methylenetetrahydrofolate } \\
\text { dehydrogenase } 1\end{array}$ & 105.89 & 977 & 6 & 22.17 & 0 & 4 & $\mathrm{~N}$ & Cytoplasm & $\begin{array}{l}\text { Metabolic } \\
\text { function }\end{array}$ \\
\hline Q863C4 & ITGB6 & Integrin beta- 6 & 85.75 & 787 & 3 & 22.17 & 7 & 17 & $\mathrm{Y}$ & $\begin{array}{l}\text { Cell } \\
\text { membrane }\end{array}$ & Cell signalling \\
\hline W5QFZ8 & RPL13 & Ribosomal protein L13 & 23.41 & 203 & 2 & 22.14 & 1 & 4 & $\mathrm{~N}$ & Ribosome & Other \\
\hline W5PEE9 & LAMP1 & $\begin{array}{l}\text { Lysosomal associated } \\
\text { membrane protein } 1\end{array}$ & 42.1 & 392 & 3 & 22.13 & 17 & 5 & $\mathrm{~N}$ & Lysosome & $\begin{array}{l}\text { Regulatory } \\
\text { function }\end{array}$ \\
\hline W5Q9K1 & QSOX1 & Sulfhydryl oxidase & 81.6 & 747 & 5 & 22.11 & 2 & 30 & $\mathrm{Y}$ & Golgi & $\begin{array}{l}\text { Metabolic } \\
\text { function }\end{array}$ \\
\hline
\end{tabular}


Table 1. Cont

\begin{tabular}{|c|c|c|c|c|c|c|c|c|c|c|c|}
\hline \multirow{2}{*}{$\begin{array}{l}\text { Accession } \\
\text { Number }\end{array}$} & \multirow[t]{2}{*}{ Gene ID } & \multirow{2}{*}{ Protein Annotation } & \multirow{2}{*}{$\begin{array}{l}\text { Mol. Weight } \\
\text { (kDa) }\end{array}$} & \multirow{2}{*}{$\begin{array}{l}\text { Sequence } \\
\text { Length }\end{array}$} & \multirow{2}{*}{$\begin{array}{l}\text { Unique } \\
\text { Peptides }\end{array}$} & \multirow{2}{*}{$\begin{array}{l}\text { Average } \\
\text { Abundance } \\
\text { (Log } \text { LFQ }_{2}\end{array}$} & \multicolumn{2}{|c|}{$\begin{array}{l}\text { Number of Predicted } \\
\text { Glycosylation Sites }\end{array}$} & \multirow{2}{*}{$\begin{array}{l}\text { Signal } \\
\text { Peptides }\end{array}$} & \multirow{2}{*}{$\begin{array}{l}\text { Predicted } \\
\text { Cellular } \\
\text { Location }\end{array}$} & \multirow{2}{*}{$\begin{array}{l}\text { Predicted } \\
\text { Function }\end{array}$} \\
\hline & & & & & & & N-glycan & O-glycan & & & \\
\hline W5NQL2 & OLA1 & Obg-like ATPase 1 & 47.25 & 417 & 6 & 22.09 & 3 & 2 & $\mathrm{~N}$ & Nucleus & $\begin{array}{l}\text { Binding } \\
\text { function }\end{array}$ \\
\hline W5PTV7 & $\mathrm{ACE}$ & $\begin{array}{l}\text { Angiotensin-converting } \\
\text { enzyme }\end{array}$ & 138.24 & 1206 & 5 & 22.08 & 6 & 12 & $\mathrm{~N}$ & Extracellular & $\begin{array}{l}\text { Binding } \\
\text { function }\end{array}$ \\
\hline W5P375 & TCP1 & T-complex 1 & 60.52 & 558 & 6 & 22.07 & 0 & 3 & $\mathrm{~N}$ & Cytoplasm & $\begin{array}{l}\text { Regulatory } \\
\text { function }\end{array}$ \\
\hline W5PVM5 & LAMA5 & Laminin subunit alpha 5 & 375.79 & 3464 & 5 & 22.07 & 13 & 173 & $\mathrm{~N}$ & Extracellular & $\begin{array}{l}\text { Regulatory } \\
\text { function }\end{array}$ \\
\hline W5QC22 & $\mathrm{CD} 47$ & CD47 molecule & 32.16 & 291 & 3 & 22.07 & 5 & 4 & $\mathrm{~N}$ & Extracellular & $\begin{array}{l}\text { Immune } \\
\text { response }\end{array}$ \\
\hline W5QCP9 & COL6A3 & $\begin{array}{l}\text { Collagen type VI alpha } 3 \\
\text { chain, von Willebrand } \\
\text { factor A domain }\end{array}$ & 340.43 & 3154 & 6 & 22 & 6 & 86 & $\mathrm{Y}$ & Extracellular & $\begin{array}{l}\text { Binding } \\
\text { function }\end{array}$ \\
\hline W5PHN8 & AKR & Aldo-keto reductase & 36.67 & 323 & 2 & 21.99 & 1 & 0 & $\mathrm{~N}$ & Cytoplasm & $\begin{array}{l}\text { Metabolic } \\
\text { function }\end{array}$ \\
\hline W5P061 & $\mathrm{ABCC} 3$ & $\begin{array}{l}\text { ATP binding cassette } \\
\text { subfamily C member } 3\end{array}$ & 169.72 & 1526 & 5 & 21.97 & 6 & 13 & $\mathrm{~N}$ & $\begin{array}{c}\text { Cell } \\
\text { membrane }\end{array}$ & Ion transport \\
\hline W5Q633 & BLVRA & Biliverdin reductase A & 33.61 & 296 & 4 & 21.94 & 0 & 0 & $\mathrm{~N}$ & Cytoplasm & $\begin{array}{l}\text { Metabolic } \\
\text { function }\end{array}$ \\
\hline W5QEY8 & GFPT1 & $\begin{array}{l}\text { Glutamine-fructose-6- } \\
\text { phosphate transaminase } \\
1\end{array}$ & 67.81 & 603 & 4 & 21.86 & 1 & 1 & $\mathrm{~N}$ & Cytoplasm & $\begin{array}{l}\text { Metabolic } \\
\text { function }\end{array}$ \\
\hline W5Q2E5 & PTPRC & $\begin{array}{c}\text { Protein tyrosine } \\
\text { phosphatase receptor } \\
\text { type C }\end{array}$ & 139.33 & 1235 & 4 & 21.83 & 19 & 55 & $\mathrm{~N}$ & $\begin{array}{l}\text { Cell } \\
\text { membrane }\end{array}$ & Cell signalling \\
\hline W5Q496 & RPL36 & $\begin{array}{c}\text { 60S ribosomal protein } \\
\text { L36 }\end{array}$ & 12.21 & 105 & 3 & 21.81 & 0 & 4 & $\mathrm{~N}$ & Ribosome & $\begin{array}{l}\text { Metabolic } \\
\text { function }\end{array}$ \\
\hline W5P6U5 & LMAN1 & $\begin{array}{l}\text { Lectin, mannose binding } \\
1\end{array}$ & 52.87 & 465 & 5 & 21.79 & 0 & 4 & $\mathrm{~N}$ & Golgi & $\begin{array}{l}\text { Protein } \\
\text { transport }\end{array}$ \\
\hline W5PK26 & LASP1 & LIM and SH3 protein 1 & 29.7 & 260 & 4 & 21.74 & 0 & 9 & $\mathrm{~N}$ & Cytoplasm & $\begin{array}{l}\text { Binding } \\
\text { function }\end{array}$ \\
\hline
\end{tabular}




\section{A}

\begin{tabular}{|c|c|c|}
\hline E Immune response & - Regulatory function & - Binding function \\
\hline Cell adhesion & - Metabolic process & n Cell signalling \\
\hline Transport & - Apoptosis & - Other \\
\hline
\end{tabular}

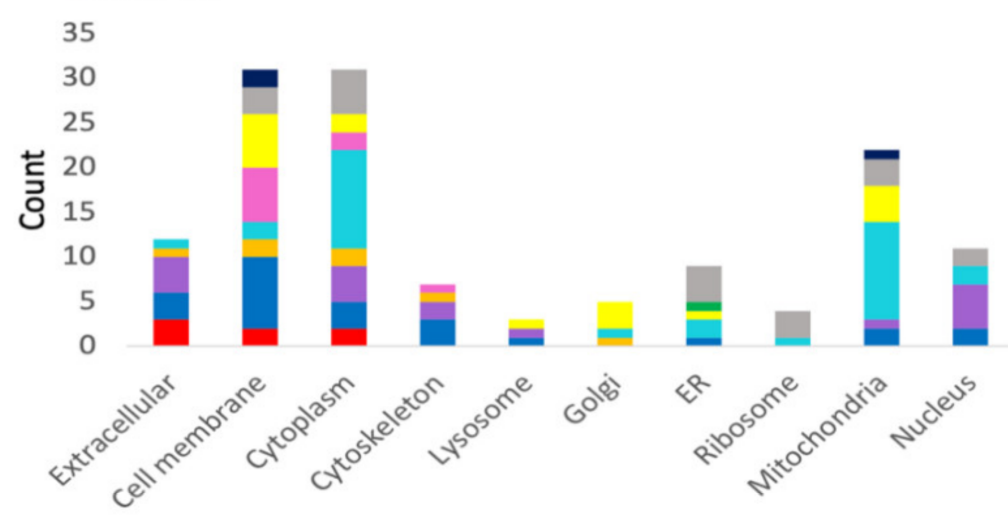

$\mathbf{B}$

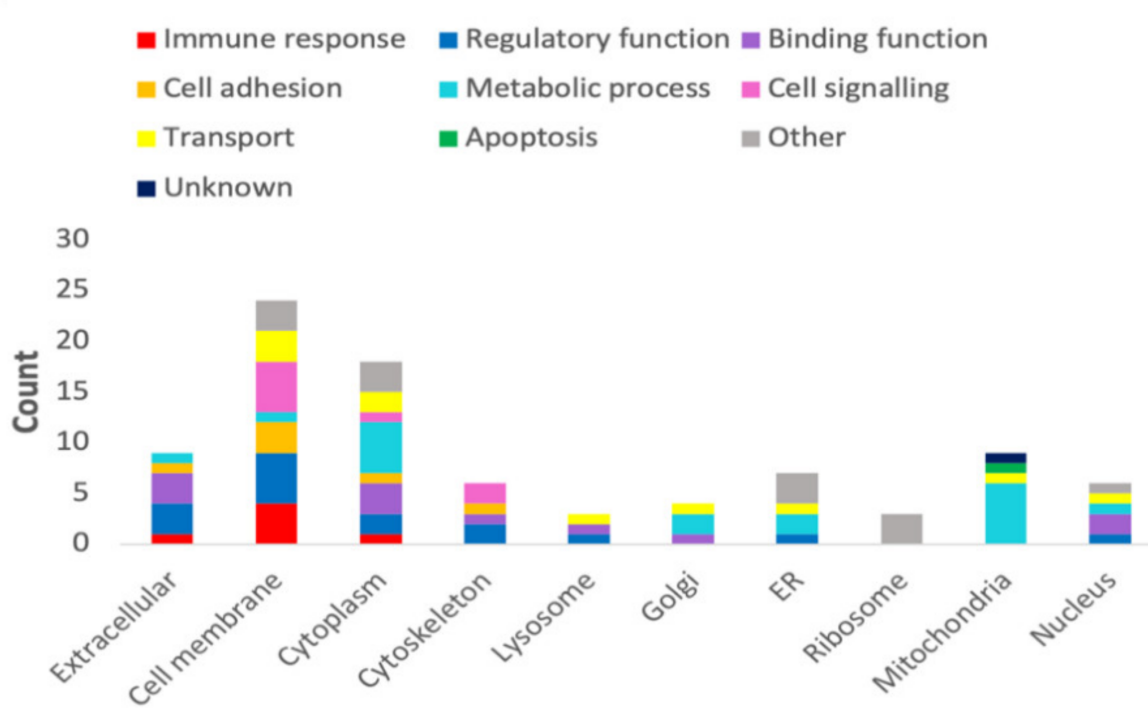

Figure 4. Characterisation of proteins in sheep abomasal tissue that interacted with Teladorsagia circumcincta galectin (Tci-gal-1). The profiles were categorised based on biological processes and cellular locations of Tci-gal-1-bound abomasal whole tissue (A) and Tci-gal-1-bound abomasal scrape tissue $(\mathbf{B})$.

From the ST pull-down, 89 unique proteins were isolated (Supplementary Table S3), with 732 proteins identified as non-specific. Similar to the WT data, a large proportion of the identified ST proteins were derived from the cell membrane (24/89) and cytoplasm $(18 / 89)$. Transmembrane domains were identified in 22 of 24 membrane proteins. This was followed by proteins in the extracellular space (9/89), mitochondria (9/89), ER (7/89), nucleus (6/89), cytoskeleton (6/89), Golgi apparatus (4/89), ribosome (3/89) and lysosome $(3 / 89)$ (Figure 4B). Seven of the 89 unique proteins had no predicted glycosylation sites (Supplementary Table S2). Non-glycosylated proteins in both datasets consisted of mainly ribonuclear transport proteins. The top 50 most abundant ST proteins are displayed in Table 2. 
Table 2. Identification by mass spectroscopy of top 50 most abundant sheep abomasal scrape tissue (ST) proteins eluted from a Tci-gal-1 column

\begin{tabular}{|c|c|c|c|c|c|c|c|c|c|c|c|}
\hline \multirow{2}{*}{$\begin{array}{l}\text { Accession } \\
\text { Number }\end{array}$} & \multirow[t]{2}{*}{ Gene ID } & \multirow{2}{*}{ Protein Annotation } & \multirow{2}{*}{$\begin{array}{l}\text { Mol. } \\
\text { Weight } \\
\text { (kDa) }\end{array}$} & \multirow{2}{*}{$\begin{array}{l}\text { Sequence } \\
\text { Length }\end{array}$} & \multirow{2}{*}{$\begin{array}{l}\text { Unique } \\
\text { Peptides }\end{array}$} & \multirow{2}{*}{$\begin{array}{l}\text { Average } \\
\text { Abundance } \\
\text { (Log } \text { LFQ }_{2} \text { ) }\end{array}$} & \multicolumn{2}{|c|}{$\begin{array}{l}\text { Number of Predicted } \\
\text { Glycosylation Sites }\end{array}$} & \multirow{2}{*}{$\begin{array}{l}\text { Signal } \\
\text { Peptides }\end{array}$} & \multirow{2}{*}{$\begin{array}{l}\text { Predicted } \\
\text { Cellular } \\
\text { Location }\end{array}$} & \multirow{2}{*}{$\begin{array}{l}\text { Predicted } \\
\text { Function }\end{array}$} \\
\hline & & & & & & & N-glycan & O-glycan & & & \\
\hline W5PLZ4 & TFF2 & Trefoil factor 2 & 14.31 & 131 & 2 & 24.21 & 0 & 1 & Y & Extracellular & $\begin{array}{l}\text { Regulatory } \\
\text { function }\end{array}$ \\
\hline W5QAH5 & - & $\begin{array}{l}\text { Transcription factor, } \\
\text { GTP-binding domain }\end{array}$ & 30.79 & 277 & 1 & 23.93 & 2 & 1 & $\mathrm{~N}$ & Nucleus & Other \\
\hline W5PQ79 & RPS15 & Ribosomal protein S15 & 16.43 & 141 & 2 & 23.8 & 0 & 0 & $\mathrm{~N}$ & Ribosome & Other \\
\hline W5P5W1 & ITGA3 & Integrin subunit alpha 3 & 115.18 & 1039 & 10 & 23.64 & 11 & 4 & $\mathrm{Y}$ & $\begin{array}{l}\text { Cell } \\
\text { membrane }\end{array}$ & Cell signalling \\
\hline W5PBS4 & LRP1 & $\begin{array}{l}\text { LDL receptor related } \\
\text { protein } 1\end{array}$ & 502.55 & 4526 & 14 & 22.89 & 33 & 122 & $\mathrm{~N}$ & $\begin{array}{l}\text { Cell } \\
\text { membrane }\end{array}$ & $\begin{array}{l}\text { Regulatory } \\
\text { function }\end{array}$ \\
\hline W5PEN0 & ITGA1 & Integrin subunit alpha 1 & 129.29 & 1166 & 9 & 22.86 & 19 & 15 & $\mathrm{Y}$ & $\begin{array}{l}\text { Cell } \\
\text { membrane }\end{array}$ & $\begin{array}{l}\text { Regulatory } \\
\text { function }\end{array}$ \\
\hline W5P1J8 & $\mathrm{CAO}$ & Copper amine oxidase & 85.25 & 766 & 3 & 22.71 & 4 & 11 & Y & Cytoplasm & $\begin{array}{l}\text { Metabolic } \\
\text { function }\end{array}$ \\
\hline Q863C4 & ITGB6 & Integrin beta- 6 & 85.75 & 787 & 3 & 22.58 & 7 & 17 & $\mathrm{Y}$ & $\begin{array}{l}\text { Cell } \\
\text { membrane }\end{array}$ & Cell signalling \\
\hline W5Q9K1 & QSOX1 & Sulfhydryl oxidase & 81.6 & 747 & 5 & 22.46 & 2 & 30 & $\mathrm{Y}$ & Golgi & $\begin{array}{l}\text { Metabolic } \\
\text { function }\end{array}$ \\
\hline W5NVK4 & SPCS1 & $\begin{array}{l}\text { Signal peptidase complex } \\
\text { subunit } 1\end{array}$ & 18.11 & 163 & 1 & 22.34 & 1 & 2 & $\mathrm{~N}$ & ER & Other \\
\hline W5NY03 & CD163 & $\begin{array}{l}\text { CD163, scavenger } \\
\text { receptor cysteine rich } \\
\text { domain }\end{array}$ & 122.35 & 1136 & 6 & 22.3 & 7 & 13 & $\mathrm{Y}$ & $\begin{array}{l}\text { Cell } \\
\text { membrane }\end{array}$ & Cell signalling \\
\hline W5P3H8 & IGF2R & $\begin{array}{l}\text { Insulin like growth factor } \\
2 \text { receptor, } \\
\text { mannose-6-phosphate } \\
\text { receptor }\end{array}$ & 271.7 & 2463 & 7 & 22.28 & 16 & 13 & $\mathrm{~N}$ & Golgi & $\begin{array}{l}\text { Binding } \\
\text { function }\end{array}$ \\
\hline W5PVR9 & ERMP1 & $\begin{array}{l}\text { Endoplasmic reticulum } \\
\text { metallopeptidase } 1\end{array}$ & 100.02 & 905 & 4 & 22.28 & 2 & 5 & $\mathrm{~N}$ & ER & $\begin{array}{l}\text { Metabolic } \\
\text { function }\end{array}$ \\
\hline W5QA42 & MFAP4 & $\begin{array}{l}\text { Fibrinogen C-terminal } \\
\text { domain-containing } \\
\text { protein }\end{array}$ & 21.42 & 193 & 2 & 22.21 & 1 & 0 & $\mathrm{Y}$ & Extracellular & $\begin{array}{l}\text { Metabolic } \\
\text { function }\end{array}$ \\
\hline W5QCH8 & NPTN & Neuroplastin & 42.43 & 376 & 6 & 22.21 & 4 & 3 & $\mathrm{~N}$ & $\begin{array}{l}\text { Cell } \\
\text { membrane }\end{array}$ & Cell adhesion \\
\hline
\end{tabular}


Table 2. Cont

\begin{tabular}{|c|c|c|c|c|c|c|c|c|c|c|c|}
\hline \multirow{2}{*}{$\begin{array}{l}\text { Accession } \\
\text { Number }\end{array}$} & \multirow{2}{*}{ Gene ID } & \multirow{2}{*}{ Protein Annotation } & \multirow{2}{*}{$\begin{array}{l}\text { Mol. } \\
\text { Weight } \\
\text { (kDa) }\end{array}$} & \multirow{2}{*}{$\begin{array}{l}\text { Sequence } \\
\text { Length }\end{array}$} & \multirow{2}{*}{$\begin{array}{l}\text { Unique } \\
\text { Peptides }\end{array}$} & \multirow{2}{*}{$\begin{array}{c}\text { Average } \\
\text { Abundance } \\
\text { ( } \log _{2} \text { LFQ) }\end{array}$} & \multicolumn{2}{|c|}{$\begin{array}{c}\text { Number of Predicted } \\
\text { Glycosylation Sites }\end{array}$} & \multirow{2}{*}{$\begin{array}{c}\text { Signal } \\
\text { Peptides }\end{array}$} & \multirow{2}{*}{$\begin{array}{l}\text { Predicted } \\
\text { Cellular } \\
\text { Location }\end{array}$} & \multirow{2}{*}{$\begin{array}{l}\text { Predicted } \\
\text { Function }\end{array}$} \\
\hline & & & & & & & N-glycan & O-glycan & & & \\
\hline W5P6A5 & SPINT2 & $\begin{array}{c}\text { Serine peptidase } \\
\text { inhibitor, Kunitz type } 2\end{array}$ & 27.96 & 250 & 2 & 22.17 & 2 & 9 & $\mathrm{Y}$ & $\begin{array}{c}\text { Cell } \\
\text { membrane }\end{array}$ & $\begin{array}{l}\text { Regulatory } \\
\text { function }\end{array}$ \\
\hline W5PEE9 & LAMP1 & $\begin{array}{l}\text { Lysosomal associated } \\
\text { membrane protein } 1\end{array}$ & 42.1 & 392 & 3 & 22.15 & 17 & 5 & $\mathrm{~N}$ & Lysosome & $\begin{array}{l}\text { Regulatory } \\
\text { function }\end{array}$ \\
\hline W5QC22 & CD47 & CD47 molecule & 32.16 & 291 & 3 & 22.12 & 5 & 4 & $\mathrm{~N}$ & $\begin{array}{l}\text { Cell } \\
\text { membrane }\end{array}$ & Cell adhesion \\
\hline W5NTX6 & RIPK1 & $\begin{array}{c}\text { Receptor interacting } \\
\text { serine/threonine kinase } \\
1\end{array}$ & 87.21 & 770 & 1 & 22.1 & 2 & 38 & $\mathrm{~N}$ & Cytoplasm & $\begin{array}{l}\text { Regulatory } \\
\text { function }\end{array}$ \\
\hline W5PTV7 & $\mathrm{ACE}$ & $\begin{array}{l}\text { Angiotensin-converting } \\
\text { enzyme }\end{array}$ & 138.24 & 1206 & 5 & 22.07 & 6 & 12 & $\mathrm{~N}$ & Extracellular & $\begin{array}{l}\text { Binding } \\
\text { function }\end{array}$ \\
\hline W5P1H4 & CTL4 & $\begin{array}{l}\text { Choline transporter-like } \\
\text { protein } 4\end{array}$ & 79.6 & 711 & 3 & 21.98 & 8 & 6 & $\mathrm{~N}$ & $\begin{array}{c}\text { Cell } \\
\text { membrane }\end{array}$ & $\begin{array}{l}\text { Membrane } \\
\text { transport }\end{array}$ \\
\hline W5P180 & MTX1 & Metaxin & 32.19 & 285 & 4 & 21.95 & 0 & 5 & $\mathrm{~N}$ & Mitochondria & $\begin{array}{l}\text { Protein } \\
\text { transport }\end{array}$ \\
\hline W5Q0Z6 & MCAM & $\begin{array}{l}\text { Melanoma cell adhesion } \\
\text { molecule } \\
\text { (MUC18-related) }\end{array}$ & 68.13 & 615 & 11 & 21.9 & 6 & 6 & $\mathrm{~N}$ & $\begin{array}{c}\text { Cell } \\
\text { membrane }\end{array}$ & $\begin{array}{l}\text { Immune } \\
\text { response }\end{array}$ \\
\hline W5QG70 & MUC13 & $\begin{array}{l}\text { SEA domain-containing } \\
\text { protein }\end{array}$ & 53.93 & 508 & 2 & 21.79 & 9 & 62 & $\mathrm{Y}$ & $\begin{array}{l}\text { Cell } \\
\text { membrane }\end{array}$ & Cell signalling \\
\hline W5NYN6 & RTN3 & Reticulon & 111.06 & 1028 & 1 & 21.78 & 1 & 151 & $\mathrm{~N}$ & ER & Other \\
\hline W5P0R5 & RPL21E & Ribosomal protein L21e & 18.41 & 160 & 1 & 21.71 & 0 & 0 & $\mathrm{~N}$ & Ribosome & Other \\
\hline W5Q8Y5 & HDLBP & $\begin{array}{l}\text { High density lipoprotein } \\
\text { binding protein/Vigilin } \\
\text { Glutamine }\end{array}$ & 141.91 & 1273 & 3 & 21.71 & 0 & 30 & $\mathrm{~N}$ & Nucleus & $\begin{array}{l}\text { Binding } \\
\text { function }\end{array}$ \\
\hline W5PQ27 & GATD3A & $\begin{array}{l}\text { Amidotransferase Like } \\
\text { Class } 1 \text { Domain } \\
\text { Containing } 3 \mathrm{~A}\end{array}$ & 28.69 & 274 & 4 & 21.66 & 1 & 8 & $\mathrm{Y}$ & Mitochondria & Unknown \\
\hline W5PK26 & LASP1 & LIM and $\mathrm{SH} 3$ protein 1 & 29.7 & 260 & 4 & 21.66 & 0 & 9 & $\mathrm{~N}$ & Cytoplasm & $\begin{array}{l}\text { Binding } \\
\text { function }\end{array}$ \\
\hline W5Q501 & GNAS & GNAS complex locus & 111.42 & 1037 & 3 & 21.63 & 1 & 71 & $\mathrm{~N}$ & Cytoplasm & Cell signalling \\
\hline W5PQS4 & PROCR & $\begin{array}{l}\text { MHC class 1-like antigen } \\
\text { recognition domain }\end{array}$ & 27.09 & 241 & 3 & 21.61 & 4 & 1 & $\mathrm{Y}$ & Cytoskeleton & Cell signalling \\
\hline
\end{tabular}


Table 2. Cont

\begin{tabular}{|c|c|c|c|c|c|c|c|c|c|c|c|}
\hline \multirow{2}{*}{$\begin{array}{l}\text { Accession } \\
\text { Number }\end{array}$} & \multirow{2}{*}{ Gene ID } & \multirow{2}{*}{ Protein Annotation } & \multirow{2}{*}{$\begin{array}{l}\text { Mol. } \\
\text { Weight } \\
\text { (kDa) }\end{array}$} & \multirow{2}{*}{$\begin{array}{l}\text { Sequence } \\
\text { Length }\end{array}$} & \multirow{2}{*}{$\begin{array}{l}\text { Unique } \\
\text { Peptides }\end{array}$} & \multirow{2}{*}{$\begin{array}{c}\text { Average } \\
\text { Abundance } \\
\text { ( } \log _{2} \text { LFQ) }\end{array}$} & \multicolumn{2}{|c|}{$\begin{array}{c}\text { Number of Predicted } \\
\text { Glycosylation Sites }\end{array}$} & \multirow{2}{*}{$\begin{array}{c}\text { Signal } \\
\text { Peptides }\end{array}$} & \multirow{2}{*}{$\begin{array}{l}\text { Predicted } \\
\text { Cellular } \\
\text { Location }\end{array}$} & \multirow{2}{*}{$\begin{array}{l}\text { Predicted } \\
\text { Function }\end{array}$} \\
\hline & & & & & & & N-glycan & O-glycan & & & \\
\hline W5QJ31 & MTHFD1 & $\begin{array}{l}\text { Methylenetetrahydrofolate } \\
\text { dehydrogenase } 1\end{array}$ & 105.89 & 977 & 6 & 21.61 & 0 & 4 & $\mathrm{~N}$ & Cytoplasm & $\begin{array}{l}\text { Metabolic } \\
\text { function }\end{array}$ \\
\hline W5PVM5 & LAMA5 & Laminin subunit alpha 5 & 375.79 & 3464 & 5 & 21.6 & 13 & 173 & $\mathrm{~N}$ & Extracellular & $\begin{array}{l}\text { Regulatory } \\
\text { function }\end{array}$ \\
\hline W5QFP1 & PABPC4 & $\begin{array}{l}\text { Polyadenylate-binding } \\
\text { protein }\end{array}$ & 72.31 & 660 & 2 & 21.6 & 0 & 8 & $\mathrm{~N}$ & Cytoplasm & $\begin{array}{l}\text { Binding } \\
\text { function }\end{array}$ \\
\hline W5PD64 & ARL8B & $\begin{array}{c}\text { ADP ribosylation } \\
\text { factor-like GTPase 8B }\end{array}$ & 20.41 & 176 & 3 & 21.57 & 2 & 0 & $\mathrm{~N}$ & Lysosome & $\begin{array}{l}\text { Binding } \\
\text { function }\end{array}$ \\
\hline W5PDH7 & NPC1 & $\begin{array}{l}\text { Niemann-Pick C type } \\
\text { protein }\end{array}$ & 141.53 & 1275 & 4 & 21.54 & 14 & 9 & $\mathrm{Y}$ & Lysosome & $\begin{array}{l}\text { Lipid } \\
\text { transport }\end{array}$ \\
\hline W5P066 & CYB5B & Cytochrome b5 type B & 16.98 & 153 & 2 & 21.49 & 0 & 1 & $\mathrm{~N}$ & Mitochondria & $\begin{array}{l}\text { Metabolic } \\
\text { function }\end{array}$ \\
\hline W5P900 & RPL29 & $\begin{array}{l}\text { 60S ribosomal protein } \\
\text { L29 }\end{array}$ & 17.13 & 156 & 2 & 21.48 & 2 & 0 & $\mathrm{~N}$ & Ribosome & Other \\
\hline W5P246 & TM9SF2 & Nonaspanin & 76.13 & 666 & 3 & 21.46 & 0 & 2 & Y & $\begin{array}{c}\text { Cell } \\
\text { membrane }\end{array}$ & $\begin{array}{l}\text { Membrane } \\
\text { transport }\end{array}$ \\
\hline W5P1G5 & ERGIC1 & $\begin{array}{l}\text { Endoplasmic } \\
\text { reticulum-golgi } \\
\text { intermediate } \\
\text { compartment } 1\end{array}$ & 32.62 & 290 & 1 & 21.46 & 1 & 0 & $\mathrm{~N}$ & Nucleus & $\begin{array}{l}\text { ER-Golgi } \\
\text { transport }\end{array}$ \\
\hline W5P906 & DPP4 & Dipeptidyl peptidase 4 & 88.44 & 765 & 3 & 21.45 & 9 & 7 & $\mathrm{Y}$ & $\begin{array}{l}\text { Cell } \\
\text { membrane }\end{array}$ & $\begin{array}{l}\text { Metabolic } \\
\text { function }\end{array}$ \\
\hline W5PWS0 & CD46 & $\begin{array}{l}\text { Membrane cofactor } \\
\text { protein CD46 }\end{array}$ & 39.43 & 363 & 3 & 21.35 & 3 & 10 & $\mathrm{Y}$ & $\begin{array}{l}\text { Cell } \\
\text { membrane }\end{array}$ & $\begin{array}{l}\text { Immune } \\
\text { response }\end{array}$ \\
\hline W5PZG7 & PECAM1 & $\begin{array}{l}\text { Platelet and endothelial } \\
\text { cell adhesion molecule } 1 \\
\text { (Ig-like) }\end{array}$ & 90.96 & 812 & 3 & 21.35 & 11 & 2 & $\mathrm{~N}$ & Extracellular & $\begin{array}{l}\text { Immune } \\
\text { response }\end{array}$ \\
\hline W5QG66 & ITGB5 & Integrin beta- 5 & 88.13 & 802 & 3 & 21.31 & 5 & 25 & $\mathrm{~N}$ & $\begin{array}{l}\text { Cell } \\
\text { membrane }\end{array}$ & Cell signalling \\
\hline W5P8N8 & IDH3B & $\begin{array}{l}\text { Isocitrate dehydrogenase } \\
\text { [NAD] subunit }\end{array}$ & 42.5 & 385 & 4 & 21.27 & 0 & 6 & $\mathrm{~N}$ & Mitochondria & $\begin{array}{l}\text { Metabolic } \\
\text { function }\end{array}$ \\
\hline W5PXR3 & ENPP1 & $\begin{array}{l}\text { Ectonucleotide pyrophos- } \\
\text { phatase/phosphodiesterase } \\
1\end{array}$ & 94.68 & 823 & 4 & 21.27 & 6 & 8 & $\mathrm{~N}$ & Extracellular & $\begin{array}{l}\text { Regulatory } \\
\text { function }\end{array}$ \\
\hline W5Q3J8 & HLA-DRB3 & $\begin{array}{c}\text { MHC class II antigen } \\
\text { DRB3 }\end{array}$ & 27.99 & 244 & 2 & 21.23 & 1 & 1 & $\mathrm{Y}$ & $\begin{array}{l}\text { Cell } \\
\text { membrane }\end{array}$ & $\begin{array}{l}\text { Immune } \\
\text { response }\end{array}$ \\
\hline
\end{tabular}


The pull-down assays from both tissue types showed a large proportion of overlapping proteins, with 63 proteins observed to be present in both datasets (Figure 5). The extracellular immune protein trefoil factor 2 (TFF2) presented as the most abundant protein in ST samples and the second most abundant in WT samples, alongside other important immune proteins such as integrins, immunoglobulins, major histocompatibility complex (MHC) domains, and an angiotensin-converting enzyme (ACE). Another notable protein was the sea urchin sperm, enterokinase and agrin (SEA) domain-containing proteins which was present in both datasets and are related to mucins, along with an Fc fragment of IgG binding protein (FCGBP) in the WT sample.

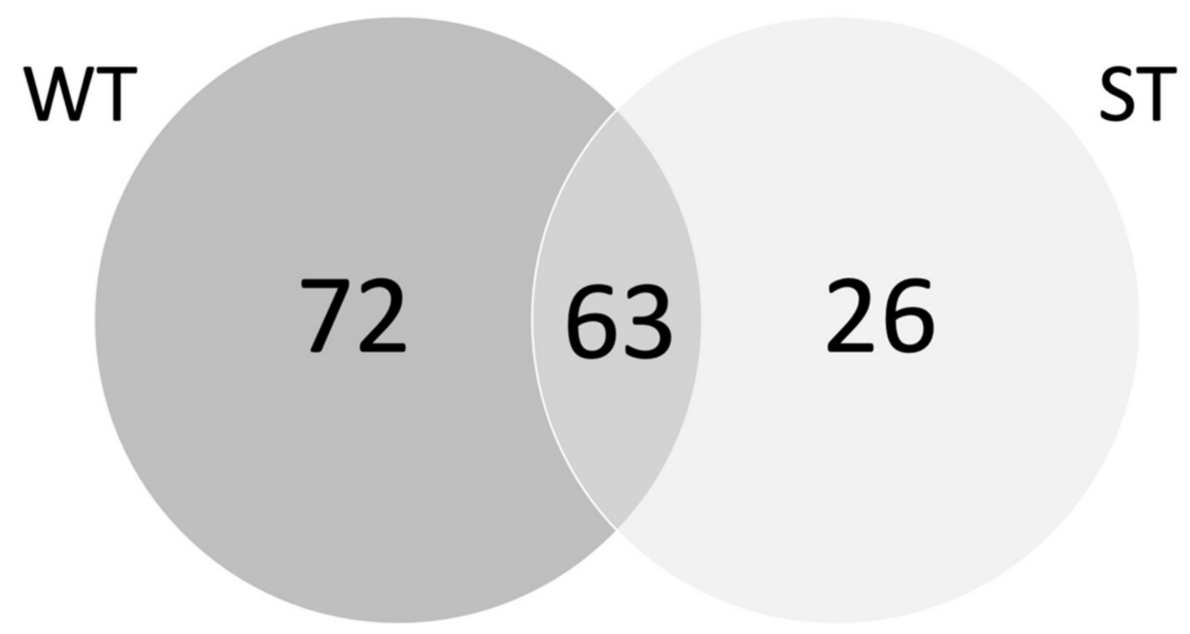

Figure 5. Venn diagram showing the distribution of sheep abomasal whole tissue (WT) and abomasal scrape tissue (ST) that specifically bound to Teladorsagia circumcincta galectin (Tci-gal-1).

\section{Discussion}

T. circumcincta galectin (Tci-gal-1) has the potential to modulate the host immune response [20]. However, the function of this parasite galectin remains to be elucidated. This study demonstrates that functional Tci-gal- 1 can be expressed and purified from a yeast expression system, allowing for the identification of ligands from sheep abomasum whole and scrape tissue using mass spectrometry. A total of 135 proteins from abomasal tissue and 89 proteins from surface scrapes bound Tci-gal-1-conjugated resin in a carbohydrate-dependent manner. Of these proteins, 63 were present in both tissue types. The investigation of these ovine abomasal proteins focused on extracellular and membrane proteins, as parasite derived galectin is unlikely to interact with the subcellular proteins in the mitochondria, cytoskeleton, ER and ribosome during infection [24]. This study indicates that Tci-gal-1 interacts with an array of host glycoproteins, potentially including interactions important for parasite survival. However, it should be noted that the abomasum tissue was obtained from sheep killed at the local abattoir; thus, their life histories could not be obtained and therefore we do not know about previous infections or treatment for infection such drenching. Several studies have suggested the results from large experimental single infections may not reflect the same immune response as a natural infection which occurs gradually [31-33]. As such, we think proteins identified from tissue obtained from sheep grazed under natural conditions would be representative of what is happening at the host-parasite interface.

The membrane protein TFF2 was a highly abundant protein identified in both sample types. Trefoil factors are cysteine-rich proteins that are secreted in mucus, forming complex structures with mucins that can influence mucus viscosity [34,35]. The trefoil factor family (TFF) consists of three peptide variants: TFF1, TFF2 and TFF3 [34,36]. This family of proteins are typically expressed in response to mucosal damage [36]. Previous findings have shown that all three members of the TFF are rapidly induced upon injury, with TFF2 being upregulated as quickly as 30 min post-injury [36]. TFF2 has two trefoil domains, compared 
to one domain in the other variants, and is more compact in structure, which produces a higher viscosity upon interaction with mucins [34]. TFF2 may aid in nematode expulsion as shown in a study in mice infected with the hookworm Nippostrongylus brasiliensis which showed a higher worm burden in TFF2 deficient mice [37]. Tc-gal-1 potential aids parasite survival by reducing expulsion by mucus by interfering with TFF2's ability to increase mucus viscosity. Mucins and TFF act in conjunction with calcium activated chloride channels (CLCA1) in the membrane to influence mucus hydration via osmotic fluid transfer, ultimately altering mucus viscosity [38].

Several immunoglobulin (Ig) domains were also identified as Tci-gal-1 interacting partners in the extracellular space, such as the FCGBP, several cluster of differentiation molecules and an immunoglobulin-like cell adhesion molecule. GI nematode infections are correlated with an increased Th2-type immune response, indicated by increased levels of Th2 cytokines, granular and globular leukocytes and parasite-specific antibodies that include IgA, IgG1 and IgE [39]. Elevated IgA levels in sheep are positively correlated with $T$. circumcincta resistance, with worm length and fecundity being significantly diminished $[39,40]$. IgA from the gastrointestinal tract can bind to parasites or their E/S antigens, with higher levels of parasite-specific IgA found in resistant sheep [41]. On the other hand, IgE is strongly associated with immune responses against parasitic infections including T. circumcincta [42]. IgE can act with larval-specific IgG1 to mediate helminth expulsion, as demonstrated in Merino lambs resistant to H. contortus [43]. Parasite galectins are known to bind IgE [20] and galectin may act as a molecular sponge to soak up antibodies and inhibit antibody function [20]. The identification of Ig domain-containing proteins suggest that Tci-gal-1 can interact with a range of antibodies and the Ig superfamily of proteins to regulate an environment that aids in parasite survival.

A range of surface exposed cluster of differentiation (CD) molecules were also identified in both samples. CD antigens are expressed by different subsets of cells as the cells differentiate along specific myeloid and lymphoid lineages. For example, CD47, CD54 and CD63 identified in this dataset are associated with and form complexes with integrins, affecting cell function and are essential in immune responses [44-46].

Several mucin-like proteins were identified in this study: a mucin 1 (MUC1)-like protein, mucin 13 (MUC13)-related protein and a mucin 18 (MUC18)-related protein. Mucus is a gel-like substance that coats the GI epithelium and can act as a physical barrier, which prevents the establishment of pathogens in the host [35,47]. Mucus possesses additional functions that include the presentation of specific ligands to trap pathogens [35], possibly preventing parasitic nematodes like T. circumcincta from penetrating host abomasal glands [10]. Mucus is mainly comprised of high molecular weight (>1 MDa), heavily Oglycosylated glycoproteins known as mucins $[35,48,49]$. Mucins can be categorised into two main subtypes: secreted mucins and membrane-bound or transmembrane mucins $[35,50]$. Secreted mucins are responsible for the gel-like and viscous property of mucus while transmembrane mucins have both barrier and signalling functions [47].

In addition to mucus proteins, SEA domains related to MUC1 and MUC13 were identified in the datasets. SEA domains are hypothesised to reduce the impacts of mechanical stress, as they are located in extracellular regions of transmembrane mucins and break at their proteolytic cleavage point upon force and reduce the effects of mechanical manipulation [51,52]. Both MUC1 and MUC13 possess a single SEA domain on the C-terminal of their mucin domains [52]. MUC1 is a major gastric transmembrane mucin with anti-inflammatory properties that is critical in the defence against enteropathogenic bacteria [47,53]. Glycosylated tandem repeats of MUC1 can extend up to $500 \mathrm{~nm}$ above the epithelial cell surface, forming a dense glycocalyx impermeable to bacterial pathogens [47]. MUC1 is continually internalised by clathrin-mediated endocytosis and recycled back to the cell surface, expanding its carrying capacity [53]. A clathrin adaptor, a key component of clathrin-mediated endocytosis, was identified in this study. Conversely, MUC13 is a membrane-associated sialomucin typically expressed in the intestinal tract with more pro-inflammatory characteristics [53]. The identification of both mucin-like proteins and 
the key SEA domain highlights a potential major role of Tci-gal-1 to alter the composition of mucus and thus facilitate parasite establishment and survival.

A melanoma cell adhesion molecule (MCAM), also known as MUC18 or CD146, was isolated from abomasal scrape samples. MUC18 is part of the immunoglobulin superfamily, consisting of five Ig domains, and is important in inflammatory responses [54]. It has been shown that Muc18 is most abundant mucin detected in gills of gilthead sea bream and gene expression of muc18 is down regulated upon infection [55,56]. In both fish and sheep, the role of this mucin's contribution to the stability of the mucus glycocalyx remains to be investigated.

Integrins were also amongst the top 50 most abundant proteins across both datasets, particularly ITGA1, ITGA3 and ITGB6. These cell surface receptors are comprised of an $\alpha$ and $\beta$ subunit, with combinations of the two subunits resulting in unique binding and signalling specificities [57]. Involved in multiple signalling pathways, these glycoproteins interact with a variety of extracellular matrix proteins such as kinases, fibronectin, collagen and other molecules to mediate activities in the extracellular matrix [58]. The interaction between Tci-gal-1 and integrins may hinder these signalling pathways to occur, impairing the host's natural response.

While the current approach identified a range of proteins that bind to Tc-gal- 1 that have a potential role in aiding the survival of the parasite, additional approaches such as co-immunoprecipitation and cross-linking can further verify if identified proteins interact with Tc-gal-1. Thus, further investigation into each identified glycoprotein is warranted to understand how this interaction impacts parasite pathogenesis.

\section{Conclusions}

In summary, parasite galectins can perform a wide range of functions, although their role in host-parasite interactions remain to be elucidated. This study has identified glycoprotein ligands in two types of host-derived abomasal samples that bound to Tcigal-1. In particular, Tci-gal-1 interacts with host glycoproteins such as trefoil factors, immune proteins, integrins and mucins. Strong interactions between Tci-gal-1 and mucins, in combination with other mucus-associated proteins such as trefoil factors, have the possibility to limit the efficiency of nematode expulsion by potentially altering mucus viscosity. In conclusion, this study has enhanced our understanding of the T. circumcinctasheep interface and identified novel candidates for parasite control strategies.

Supplementary Materials: The following are available online at https: / www.mdpi.com/article/ 10.3390/vetsci8100216/s1. Figure S1: Protein sequence of recombinant Tci-gal-1 as identified by mass spectrometry. Figure S2: Circular dichroism spectra of recombinant Tci-gal-1, Table S1: Sheep proteins that were identified in the resin control, Table S2: Identification by mass spectroscopy of sheep abomasal whole tissue (WT) proteins eluted from a Tci-gal-1 column, Table S3: Identification by mass spectroscopy of sheep abomasal scrape tissue (ST) proteins eluted from a Tci-gal-1 column.

Author Contributions: Conceptualization, N.N.H., M.S. and T.B.; methodology, J.S., P.F., R.L., C.C., M.S. and T.B.; investigation, N.N.H., J.S., P.F., R.L., H.R. and C.C.; resources, M.S. and T.B.; data curation, N.N.H., J.S. and H.R.; writing — original draft preparation, N.N.H. and J.S.; writing-review and editing, N.N.H., J.S., P.F., R.L., H.R., C.C., M.S. and T.B.; supervision, M.S. and T.B.; All authors have read and agreed to the published version of the manuscript.

Funding: N.N.H. is supported by a La Trobe Research Training Program scholarship.

Institutional Review Board Statement: Ethical review was not required for this study, due to material being obtained from animals killed as part of routine commercial food and fibre production.

Informed Consent Statement: Not applicable.

Data Availability Statement: All data are contained within the article or supplementary material.

Acknowledgments: We would like to thank Radford abattoirs for providing the sheep abomasa material. 
Conflicts of Interest: The authors declare no conflict of interest.

\section{References}

1. Roeber, F.; Jex, A.R.; Gasser, R.B. Impact of gastrointestinal parasitic nematodes of sheep, and the role of advanced molecular tools for exploring epidemiology and drug resistance-An Australian perspective. Parasit. Vectors 2013, 6, 1-13. [CrossRef]

2. Charlier, J.; Thamsborg, S.M.; Bartley, D.J.; Skuce, P.J.; Kenyon, F.; Geurden, T.; Hoste, H.; Williams, A.R.; Sotiraki, S.; Hoglund, J.; et al. Mind the gaps in research on the control of gastrointestinal nematodes of farmed ruminants and pigs. Transbound. Emerg. Dis. 2018, 65 (Suppl. 1), 217-234. [CrossRef]

3. Lane, J.; Jubb, T.; Shephard, R.; Webb-Ware, J.; Fordyce, G. Final Report Priority List of Endemic Diseases for the Red Meat Industries; Meat \& Livestock Australia Limited: Sydney, Australia, 2015.

4. Charlier, J.; Rinaldi, L.; Musella, V.; Ploeger, H.W.; Chartier, C.; Vineer, H.R.; Hinney, B.; von Samson-Himmelstjerna, G.; Bacescu, B.; Mickiewicz, M.; et al. Initial assessment of the economic burden of major parasitic helminth infections to the ruminant livestock industry in Europe. Prev. Vet. Med. 2020, 182, 105103. [CrossRef]

5. Roeber, F.; Kahn, L. The specific diagnosis of gastrointestinal nematode infections in livestock: Larval culture technique, its limitations and alternative DNA-based approaches. Vet. Parasitol. 2014, 205, 619-628. [CrossRef]

6. McNeilly, T.N.; Devaney, E.; Matthews, J.B. Teladorsagia circumcincta in the sheep abomasum: Defining the role of dendritic cells in T cell regulation and protective immunity. Parasite Immunol. 2009, 31, 347-356. [CrossRef]

7. Sargison, N.D.; Jackson, F.; Bartley, D.J.; Moir, A.C.P. Failure of moxidectin to control benzimidazole-, levamisole- and ivermectinresistant Teladorsagia circumcincta in a sheep flock. Vet. Rec. 2005, 156, 105-109. [CrossRef]

8. Sutherland, I.A.; Brown, A.E.; Leathwick, D.M.; Bisset, S.A. Resistance to prophylactic treatment with macrocyclic lactone anthelmintics in Teladorsagia circumcincta. Vet. Parasitol. 2003, 115, 301-309. [CrossRef]

9. Stear, M.J.; Doligalska, M.; Donskow-Schmelter, K. Alternatives to anthelmintics for the control of nematodes in livestock. Parasitology 2007, 134, 139-151. [CrossRef] [PubMed]

10. Pemberton, A.D.; Brown, J.K.; Craig, N.M.; Pate, J.; McLean, K.; Inglis, N.F.; Knox, D.; Knight, P.A. Changes in protein expression in the sheep abomasum following trickle infection with Teladorsagia circumcincta. Parasitology 2012, 139, 375-385. [CrossRef] [PubMed]

11. Stear, M.J.; Bishop, S.C.; Henderson, N.G.; Scott, I. A Key Mechanism of Pathogenesis in Sheep Infected with the Nematode Teladorsagia circumcincta. Anim. Health Res. Rev. 2003, 4, 45-52. [CrossRef] [PubMed]

12. Hewitson, J.P.; Grainger, J.R.; Maizels, R.M. Helminth immunoregulation: The role of parasite secreted proteins in modulating host immunity. Mol. Biochem. Parasitol. 2009, 167, 1-11. [CrossRef] [PubMed]

13. Hoerauf, A.; Satoguina, J.; Saeftel, M.; Specht, S. Immunomodulation by filarial nematodes. Parasite Immunol. 2005, 27, 417-429. [CrossRef] [PubMed]

14. Craig, H.; Wastling, J.M.; Knox, D.P. A preliminary proteomic survey of the in vitro excretory/secretory products of fourth-stage larval and adult Teladorsagia circumcincta. Parasitology 2006, 132, 535-543. [CrossRef] [PubMed]

15. Knox, D.P. Development of vaccines against gastrointestinal nematodes. Parasitology 2000, 120, 43-61. [CrossRef] [PubMed]

16. Finlay, C.M.; Walsh, K.P.; Mills, K.H.G. Induction of regulatory cells by helminth parasites: Exploitation for the treatment of inflammatory diseases. Immunol. Rev. 2014, 259, 206-230. [CrossRef]

17. Greenhalgh, C.J.; Loukas, A.; Newton, S.E. The organization of a galectin gene from Teladorsagia circumcincta. Mol. Biochem. Parasitol. 1999, 101, 199-206. [CrossRef]

18. Rabinovich, G.A.; Toscano, M.A. Turning 'sweet' on immunity: Galectin-glycan interactions in immune tolerance and inflammation. Nat. Rev. Immunol. 2009, 9, 338-352. [CrossRef]

19. Shi, W.; Xue, C.; Su, X.Z.; Lu, F. The roles of galectins in parasitic infections. Acta Trop. 2018, 177, 97-104. [CrossRef]

20. Donskow-Lysoniewska, K.; Maruszewska-Cheruiyot, M.; Stear, M. The interaction of host and nematode galectins influences the outcome of gastrointestinal nematode infections. Parasitology 2021, 148, 648-654. [CrossRef]

21. Hughes, R.C. Secretion of the galectin family of mammalian carbohydrate-binding proteins. Biochim. Biophys. Acta 1999, 1473, 172-185. [CrossRef]

22. Xu, J.; Yang, F.; Yang, D.Q.; Jiang, P.; Liu, R.D.; Zhang, X.; Cui, J.; Wang, Z.Q. Molecular characterization of Trichinella spiralis galectin and its participation in larval invasion of host's intestinal epithelial cells. Vet. Res. 2018, 49, 1-15. [CrossRef] [PubMed]

23. Popa, S.J.; Stewart, S.E.; Moreau, K. Unconventional secretion of annexins and galectins. Semin. Cell Dev. Biol. 2018, 83, 42-50. [CrossRef] [PubMed]

24. Vasta, G.R. Roles of galectins in infection. Nat. Rev. Immunol. 2009, 7, 424-438. [CrossRef] [PubMed]

25. Rabinovich, G.A.; Gruppi, A. Galectins as immunoregulators during infectious processes: From microbial invasion to the resolution of the disease. Parasite Immunol. 2005, 27, 103-114. [CrossRef] [PubMed]

26. Kelly, S.M.; Jess, T.J.; Price, N.C. How to study proteins by circular dichroism. Biochim. Biophys. Acta 2005, 1751, 119-139. [CrossRef] [PubMed]

27. Tran, N.H.; Qiao, R.; Xin, L.; Chen, X.; Liu, C.; Zhang, X.; Shan, B.; Ghodsi, A.; Li, M. Deep learning enables de novo peptide sequencing from data-independent-acquisition mass spectrometry. Nat. Methods 2019, 16, 63-66. [CrossRef]

28. Tyanova, S.; Temu, T.; Cox, J. The MaxQuant computational platform for mass spectrometry-based shotgun proteomics. Nat. Protoc. 2016, 11, 2301-2319. [CrossRef] 
29. Greenhalgh, C.J.; Newton, S.E. Recombinant expression of a galectin from the sheep gastrointestinal parasite Teladorsagia circumcincta: Its use in isolating galectin-glycoconjugates. Protein Express. Purif. 1999, 16, 152-159. [CrossRef]

30. Arata, Y.; Hirabayashi, J.; Kasai, K. The two lectin domains of the tandem-repeat 32-kDa galectin of the nematode Caenorhabditis elegans have different binding properties. Studies with recombinant protein. J. Biochem. 1997, 121, 1002-1009. [CrossRef]

31. Shakya, K.P.; Miller, J.E.; Lomax, L.G.; Burnett, D.D. Evaluation of immune response to artificial infections of Haemonchus contortus in Gulf Coast Native compared with Suffolk lambs. Vet Parasitol 2011, 181, 239-247. [CrossRef]

32. Aboshady, H.M.; Stear, M.J.; Johansson, A.; Jonas, E.; Bambou, J.C. Immunoglobulins as Biomarkers for Gastrointestinal Nematodes Resistance in Small Ruminants: A systematic review. Sci. Rep. 2020, 10, 7765. [CrossRef] [PubMed]

33. Munoz-Guzman, M.A.; Cuellar-Ordaz, J.A.; Valdivia-Anda, A.G.; Buendia-Jimenez, J.A.; Alba-Hurtado, F. Correlation of parasitological and immunological parameters in sheep with high and low resistance to haemonchosis. Can. J. Anim. Sci. 2006, 86, 363-371. [CrossRef]

34. Poulsen, S.S.; Kissow, H.; Hare, K.; Hartmann, B.; Thim, L. Luminal and parenteral TFF2 and TFF3 dimer and monomer in two models of experimental colitis in the rat. Regul. Pept. 2005, 126, 163-171. [CrossRef]

35. Sharpe, C.; Thornton, D.J.; Grencis, R.K. A sticky end for gastrointestinal helminths; the role of the mucus barrier. Parasite Immunol. 2018, 40,1-10. [CrossRef]

36. Taupin, D.; Podolsky, D.K. Trefoil factors: Initiators of mucosal healing. Nat. Rev. Mol. Cell Biol. 2003, 4, 721-732. [CrossRef]

37. Wills-Karp, M.; Rani, R.; Dienger, K.; Lewkowich, I.; Fox, J.G.; Perkins, C.; Lewis, L.; Finkelman, F.D.; Smith, D.E.; Bryce, P.J.; et al. Trefoil factor 2 rapidly induces interleukin 33 to promote type 2 immunity during allergic asthma and hookworm infection. $J$. Exp. Med. 2012, 209, 607-622. [CrossRef]

38. Rowe, A.; Gondro, C.; Emery, D.; Sangster, N. Sequential microarray to identify timing of molecular responses to Haemonchus contortus infection in sheep. Vet. Parasitol. 2009, 161, 76-87. [CrossRef]

39. McRae, K.M.; Stear, M.J.; Good, B.; Keane, O.M. The host immune response to gastrointestinal nematode infection in sheep. Parasite Immunol. 2015, 37, 605-613. [CrossRef]

40. Stear, M.J.; Bishop, S.C.; Doligalska, M.; Duncan, J.L.; Holmes, P.H.; Irvine, J.; McCririe, L.; McKellar, Q.A.; Sinski, E.; Murray, M. Regulation of egg production, worm burden, worm length and worm fecundity by host responses in sheep infected with Ostertagia circumcincta. Parasite Immunol. 1995, 17, 643-652. [CrossRef] [PubMed]

41. McRae, K.M.; Good, B.; Hanrahan, J.P.; Glynn, A.; O'Connell, M.J.; Keane, O.M. Response to Teladorsagia circumcincta infection in Scottish Blackface lambs with divergent phenotypes for nematode resistance. Vet. Parasitol. 2014, 206, 200-207. [CrossRef] [PubMed]

42. Murphy, L.; Eckersall, P.D.; Bishop, S.C.; Pettit, J.J.; Huntley, J.F.; Burchmore, R.; Stear, M.J. Genetic variation among lambs in peripheral IgE activity against the larval stages of Teladorsagia circumcincta. Parasitology 2010, 137, 1249-1260. [CrossRef] [PubMed]

43. Negrão-Corrêa, D. Importance of immunoglobulin E (IgE) in the protective mechanism against gastrointestinal nematode infection: Looking at the intestinal mucosae. Rev. Inst. Med. Trop. São Paulo 2001, 43, 291-299. [CrossRef]

44. Brown, E. Integrin-associated protein (CD47) and its ligands. Trends Cell Biol. 2001, 11, 130-135. [CrossRef]

45. Roebuck, K.A.; Finnegan, A. Regulation of intercellular adhesion molecule-1 (CD54) gene expression. J. Leukoc. Biol. 1999, 66, 876-888. [CrossRef] [PubMed]

46. Pols, M.S.; Klumperman, J. Trafficking and function of the tetraspanin CD63. Exp. Cell Res. 2009, 315, 1584-1592. [CrossRef]

47. van Putten, J.P.M.; Strijbis, K. Transmembrane mucins: Signaling receptors at the intersection of inflammation and cancer. J. Innate Immun. 2017, 9, 281-299. [CrossRef] [PubMed]

48. Hasnain, S.Z.; Evans, C.M.; Roy, M.; Gallagher, A.L.; Kindrachuk, K.N.; Barron, L.; Dickey, B.F.; Wilson, M.S.; Wynn, T.A.; Grencis, R.K.; et al. Muc5ac: A critical component mediating the rejection of enteric nematodes. J. Exp. Med. 2011, 208, 893-900. [CrossRef] [PubMed]

49. Pemberton, A.D.; Verdon, B.; Inglis, N.F.; Pearson, J.P. Sheep intelectin-2 co-purifies with the mucin Muc5ac from gastric mucus. Vet. Res. 2011, 91, 53-57. [CrossRef]

50. Hoorens, P.R.; Rinaldi, M.; Li, R.W.; Goddeeris, B.; Claerebout, E.; Vercruysse, J.; Geldhof, P. Genome wide analysis of the bovine mucin genes and their gastrointestinal transcription profile. BMC Genom. 2011, 12, 1-12. [CrossRef]

51. Palmai-Pallag, T.; Khodabukus, N.; Kinarsky, L.; Leir, S.H.; Sherman, S.; Hollingsworth, M.A.; Harris, A. The role of the SEA (sea urchin sperm protein, enterokinase and agrin) module in cleavage of membrane-tethered mucins. FEBS J. 2005, 272, 2901-2911. [CrossRef]

52. Pelaseyed, T.; Zach, M.; Petersson, A.C.; Svensson, F.; Johansson, D.G.; Hansson, G.C. Unfolding dynamics of the mucin SEA domain probed by force spectroscopy suggest that it acts as a cell-protective device. FEBS J. 2013, 280, 1491-1501. [CrossRef]

53. Sheng, Y.H.; Triyana, S.; Wang, R.; Das, I.; Gerloff, K.; Florin, T.H.; Sutton, P.; McGuckin, M.A. MUC1 and MUC13 differentially regulate epithelial inflammation in response to inflammatory and infectious stimuli. Mucosal Immunol. 2013, 6, 557-568. [CrossRef]

54. Shih, I.M. The role of CD146 (Mel-CAM) in biology and pathology. J. Pathol. 1999, 189, 4-11. [CrossRef]

55. Perez-Sanchez, J.; Estensoro, I.; Redondo, M.J.; Calduch-Giner, J.A.; Kaushik, S.; Sitja-Bobadilla, A. Mucins as diagnostic and prognostic biomarkers in a fish-parasite model: Transcriptional and functional analysis. PLoS ONE 2013, 8, e65457. [CrossRef] 
56. Marcos-Lopez, M.; Calduch-Giner, J.A.; Mirimin, L.; MacCarthy, E.; Rodger, H.D.; O'Connor, I.; Sitja-Bobadilla, A.; Perez-Sanchez, J.; Piazzon, M.C. Gene expression analysis of Atlantic salmon gills reveals mucin 5 and interleukin $4 / 13$ as key molecules during amoebic gill disease. Sci. Rep. 2018, 8, 13689. [CrossRef]

57. Giancotti, F.G.; Ruoslahti, E. Integrin signalling. Science 1999, 285, 1028-1032. [CrossRef]

58. Ginsberg, M.H.; Partridge, A.; Shattil, S.J. Integrin regulation. Curr. Opin. Cell Biol. 2005, 17, 509-516. [CrossRef] [PubMed] 